\title{
Geohydrologic Data from Test Hole USW UZ-6s, Yucca Mountain, Nye County, Nevada
}

\author{
by Carole L. Loskot
}

\section{U.S. GEOLOGICAL SURVEY}

Open-File Report 93-60

Prepared in cooperation with the

NEVADA FIELD OFFICE of the

U.S. DEPARTMENT OF ENERGY under

Interagency Agreement DE-Al08-78ET44802

Denver, Colorado

1993

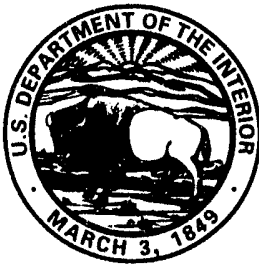




\section{U.S. DEPARTMENT OF THE INTERIOR \\ BRUCE BABBITT, Secretary}

U.S. GEOLOGICAL SURVEY

Robert M. Hirsch, Acting Director

The use of trade, product, industry, or firm names is for descriptive purposes only and does not imply endorsement by the U.S. Government.

For additional information write to:

Copies of this report can be purchased from:

Chief, Hydrologic Investigations Program U.S. Geological Survey

Yucca Mountain Project Branch

Earth Science Information Center

U.S. Geological Survey

Box 25046, MS 421

Open-File Reports Section

Denver Federal Center

Denver, CO 80225

Box 25286, MS 517

Denver Federal Center

Denver, CO 80225 


\section{CONTENTS}

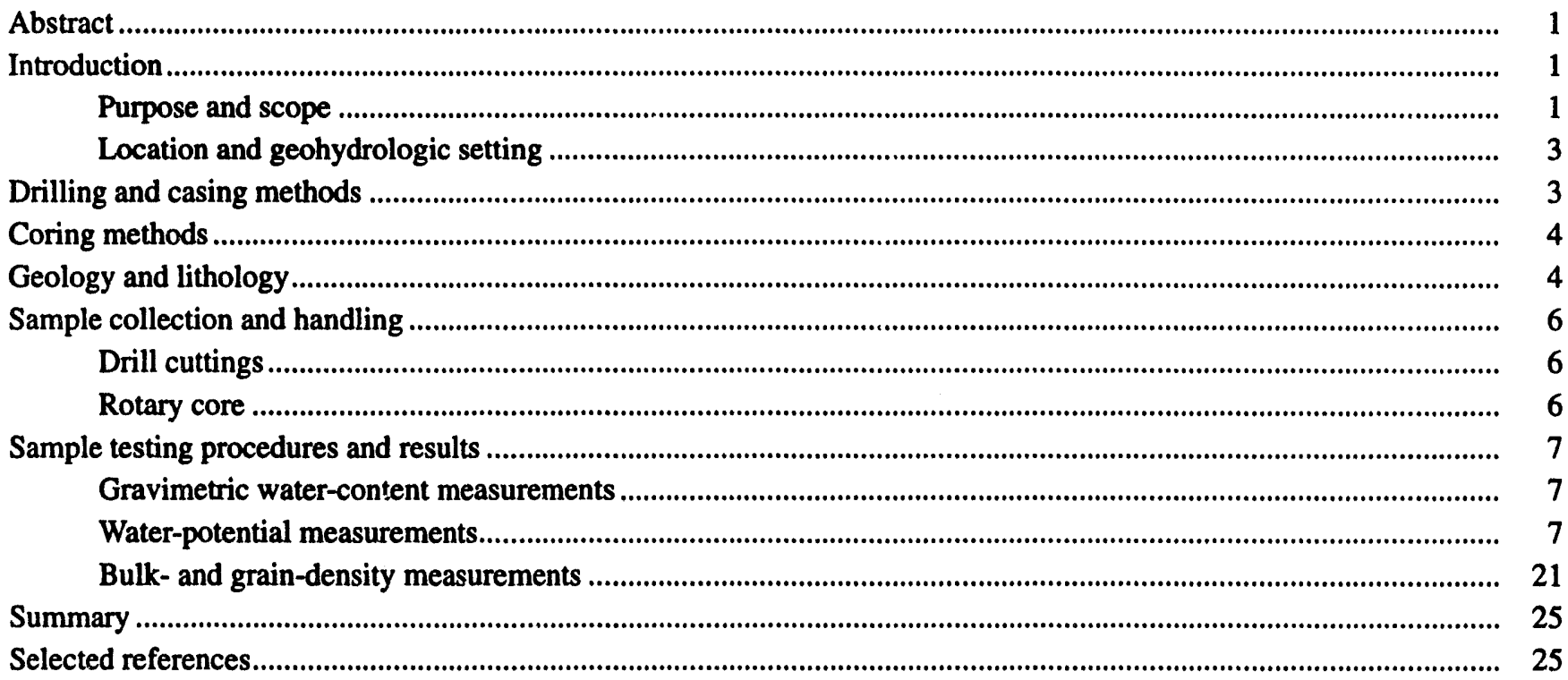

\section{FIGURES}

1. Map showing location of test holes USW UZ-6s and USW UZ-6.................................................................... 2

2. Schematic diagram showing drilling system used for test hole USW UZ-6s ........................................................ 3

3-6. Graphs showing:

3. Rotary coring drill rate and degree of welding at test hole USW UZ-6s ................................................ 5

4. Gravimetric water-content measurements from coarse-size fraction drill cuttings and composite core from test hole USW UZ-6s

5. Water-potential measurements from coarse-size fraction drill cuttings and composite core from test hole USW UZ-6s.

6. Bulk- and grain-density measurements of rotary core from test hole USW UZ-6s ..................................... 24

\section{TABLES}

1. Stratigraphic units penetrated by test hole USW UZ-6s ...............................................................................

2. Rotary-core record for test hole USW UZ-6s........................................................................................... 8

3. Resuits of laboratory analyses for gravimetric water content and water potential of coarse drill cuttings from test hole USW UZ-6s..

4. Results of laboratory analyses for gravimetric water content and water potential of composite core samples from test hole USW UZ-6s

5. Summary of relation of gravimetric water-content measurements of composite core from test hole USW UZ-6s to lithology and degree of welding.

6. Summary of relation of water-potential measurements of composite core from test hole USW UZ-6s to lithology and degree of welding

7. Results of laboratory analyses for bulk- and grain-density measurements of rotary-core samples from test hole USW UZ-6s.

8. Summary of relation of bulk- and grain-density measurements of composite core from test hole USW UZ-6s to lithology and degree of welding. 


\begin{tabular}{|c|c|c|}
\hline Multiply & By & To obtain \\
\hline $\begin{array}{r}\text { gram per cubic centimeter } \\
\text { kilometer }(\mathrm{km}) \\
\text { kilopascal }(\mathrm{Kpa}) \\
\text { kilopascal }(\mathrm{Kpa}) \\
\text { liter } \mathrm{L}) \\
\text { meter }(\mathrm{m}) \\
\text { meter per hour }(\mathrm{m} / \mathrm{hr}) \\
\text { milliliter }(\mathrm{mL}) \\
\text { millimeter }(\mathrm{mm})\end{array}$ & $\begin{array}{l}0.03613 \\
0.6214 \\
0.1450 \\
0.01 \\
1.057 \\
3.281 \\
3.281 \\
0.06102 \\
0.03937\end{array}$ & $\begin{array}{l}\text { pound per cubic inch } \\
\text { mile } \\
\text { pounds per square inch } \\
\text { bar (14.5 pounds per square inch) } \\
\text { quart } \\
\text { foot } \\
\text { feet per hour } \\
\text { cubic inch } \\
\text { inch }\end{array}$ \\
\hline
\end{tabular}

Degree Celsius $\left({ }^{\circ} \mathrm{C}\right)$ may be converted to degree Fahrenheit $\left({ }^{\circ} \mathrm{F}\right)$ by using the following equation:

$$
{ }^{\circ} \mathrm{F}=9 / 5\left({ }^{\circ} \mathrm{C}\right)+32 \text {. }
$$

Degree Fahrenheit $\left({ }^{\circ} \mathrm{F}\right)$ may be converted to degree Celsius $\left({ }^{\circ} \mathrm{C}\right)$ by using the following equation:

$$
{ }^{\circ} \mathrm{C}=5 / 9\left({ }^{\circ} \mathrm{F}-32\right) \text {. }
$$

The following terms and abbreviations also are used in this report:

gram per gram $(\mathrm{g} / \mathrm{g})$

microvolt $(\mu v)$

molality $(m)$ 


\title{
Geohydrologic Data from Test Hole USW UZ-6s, Yucca Mountain, Nye County, Nevada
}

\author{
By Carole L. Loskot
}

\section{Abstract}

As part of the investigation of Yucca Mountain, Nevada, as a potential site for storing highlevel radioactive wastes in an underground mined geologic repository, the U.S. Geological Survey, in cooperation with the U.S. Department of Energy, in 1982, began drilling a series of test holes in and near the southwestern part of the Nevada Test Site to determine the geologic and hydrologic characteristics of the area. Test hole USW UZ-6s is part of that series of test holes, and this report presents data obtained from test hole USW UZ-6s. The data include those from drilling operations, lithology, coring, and laboratory analyses of hydrologic properties, which include gravimetric water content, water potential, and bulk- and grain-density values.

The gravimetric water content of the densely welded section of the Tiva Canyon Member of the Paintbrush Tuff averages 0.027 gram per gram for test hole USW UZ-6s; water potential averages $-7,200$ kilo-pascals; gravimetric water content of the moderately to densely welded tuffs range from 0.054 gram per gram for the Tiva Canyon Member of the Paintbrush Tuff to 0.027 gram per gram for the Topopah Spring Member of the Paintbrush Tuff; and water potentials range from $-6,700$ to $-3,400$ kilopascals. Gravimetric water content for the partially welded to unnamed bedded tuffs average $0.123,0.106$, and 0.085 gram per gram for the Tiva Canyon Member, the unnamed bedded tuffs, and the Topopah Spring Member in test hole USW UZ-6s; average water potentials for these unitsare $-1,700,-480$, and-820kilopascals.

\section{INTRODUCTION}

Yucca Mountain in southwestern Nevada (fig. 1) is being studied as a potential site for storing high-level radioactive wastes in an underground mined geologic repository. In 1982, the U.S. Geological Survey, in cooperation with the U.S. Department of Energy under interagency agreement DE-AI08-78ET44802, began a series of investigations to provide information about the geology and hydrology of the area. These investigations are a part of the Yucca Mountain Project (YMP), formerly known as Nevada Nuclear Waste Storage Investigations, (NNWSI).

The principal method of investigation has been test drilling. A series of relatively shallow $(160 \mathrm{~m}$ or less) and deep (160 to $770 \mathrm{~m}$ ) unsaturated-zone test holes have been (or are projected to be) drilled at Yusca Mountain in rocks of volcanic and volcanic-clastic origin. The main objectives of this unsaturated-zone testhole program are: (1) To determine the flux of water moving through the units of the nonwelded and bedded tuff in the unsaturated rock; (2) to determine the vertical distribution of water content, water potential, and other geohydrologic characteristics in the rock units penetrated; and (3) to monitor changes in test-hole characteristics with time.

Test hole USW UZ-6s (hereinafter referred to as UZ-6s) is the sixth test hole in the series of unsaturated. zone test holes. Test hole UZ-6s was primarily drilled to provide an uncased zone for instrumentation because the upper $80.8 \mathrm{~m}$ of a nearby deeper test hole (USW UZ-6) had to be cased off during drilling. This zone was in the highly fractured, densely welded Tiva Canyon Member of the Paintbrush Tuff (Whitfield and others, 1992).

\section{Purpose and Scope}

This report presents geologic and hydrologic data collected from UZ-6s in 1985 during the drilling and coring of this test hole. These data were used to partially fulfill the second objective of the shallow, unsaturated-zone test-hole program. The report also presents data for methods for drilling, coring, sample collection and handling, and testing. The laboratory results of tests on the drill cuttings and cores obtained are included. Work done in UZ-6s was in accordance with procedures established by the YMP Quality Assurance Program. 


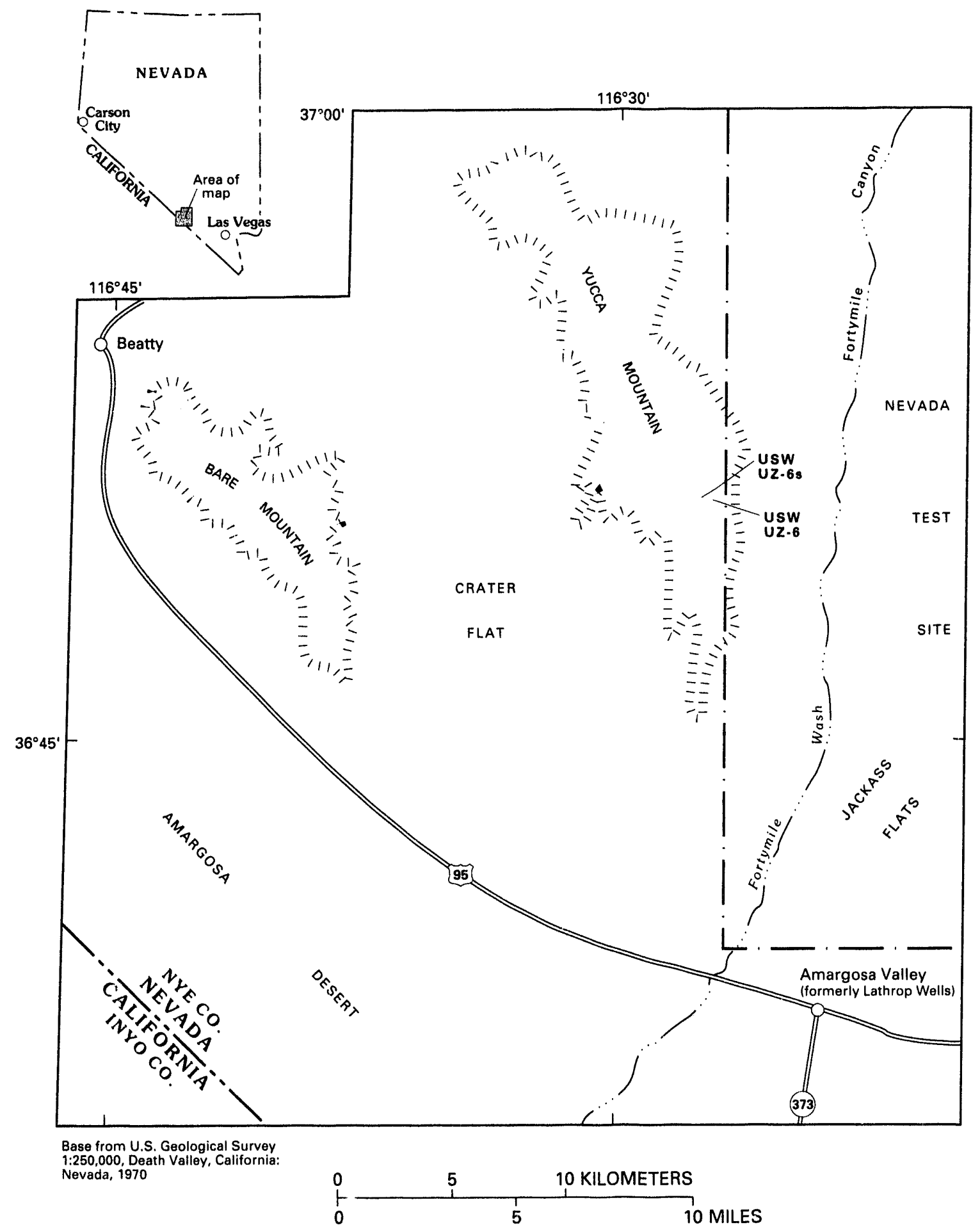

Figure 1. Location of test holes USW UZ-6s and USW UZ-6. 


\section{Location and Geohydrologic Setting}

Test hole UZ-6s is located in Nye County, Nevada, approximately $145 \mathrm{~km}$ northwest of Las Vegas near the Nevada Test Site. Coordinates of the well site are based on the Nevada State Coordinate System, Nevada Central Zone. The coordinates of UZ-6s are $\mathrm{N} 231,609.1$ and $\mathrm{E} 170,085.5 \mathrm{~m}$. Test hole UZ-6s is located on the crest of Yucca Mountain at an altitude of $1,508.52 \mathrm{~m}$, approximately $95 \mathrm{~m}$ west of test hole USW-UZ-6. Drilling and coring of UZ-6s started on April 23, 1985, and was completed June 19, 1985. Work was suspended from June 21 to August 26, 1985. From August 30, 1985, to September 6, 1985, the test hole was cleaned out and the casing removed.

Test hole UZ-6s is drilled into the Paintbrush Tuff of Miocene age to a depth of $158.2 \mathrm{~m}$. The members of the Paintbrush Tuff penetrated, in descending order, are the Tiva Canyon Member, an unnamed bedded tuff, and the Topopah Spring Member.

\section{DRILLING AND CASING METHODS}

Drilling, coring, and casing methods used in UZ-6s are described in detail by Hammermeister and others (1985); therefore, these methods are only briefly described in this report. These authors also have reported that these methods minimally disturb the water content of the formation rock, core, and, in some places, drill cuttings.

Drilling and casing of UZ-6s was conducted using the Odex 165 drilling system, which uses air as the drilling fluid. The method involves percussionhammer drilling and casing driving that are conducted simultaneously downhole. A pilot bit and an eccentric reamer are used to drill a hole slightly larger than the outside diameter (O.D.) of the casing. The percussion hammer impacts on the casing through a casing shoe attached to the bottom joint of the casing (fig. 2). Thus, the casing is advanced as the hole is drilled deeper. Drill cuttings are returned to the surface through the inside of the casing, thereby minimizing disturbance to the test-hole walls. Compressed air is injected into the casing through the drill pipe to aid in removal of drill cuttings.

A sulfur hexafluoride tracer $\left(\mathrm{SF}_{6}\right)$ was injected into test hole UZ-6s during drilling and coring from the surface to a depth of $88.4 \mathrm{~m}$, and bromochlorofluoromethane $\left(\mathrm{CBrClF}_{2}\right)$ was injected from $88.4 \mathrm{~m}$ to the total depth of the borehole at $158.2 \mathrm{~m}$. Subsequent gas sampling in the borehole will determine the presence or absence of atmospheric contamination caused by the drilling and coring.

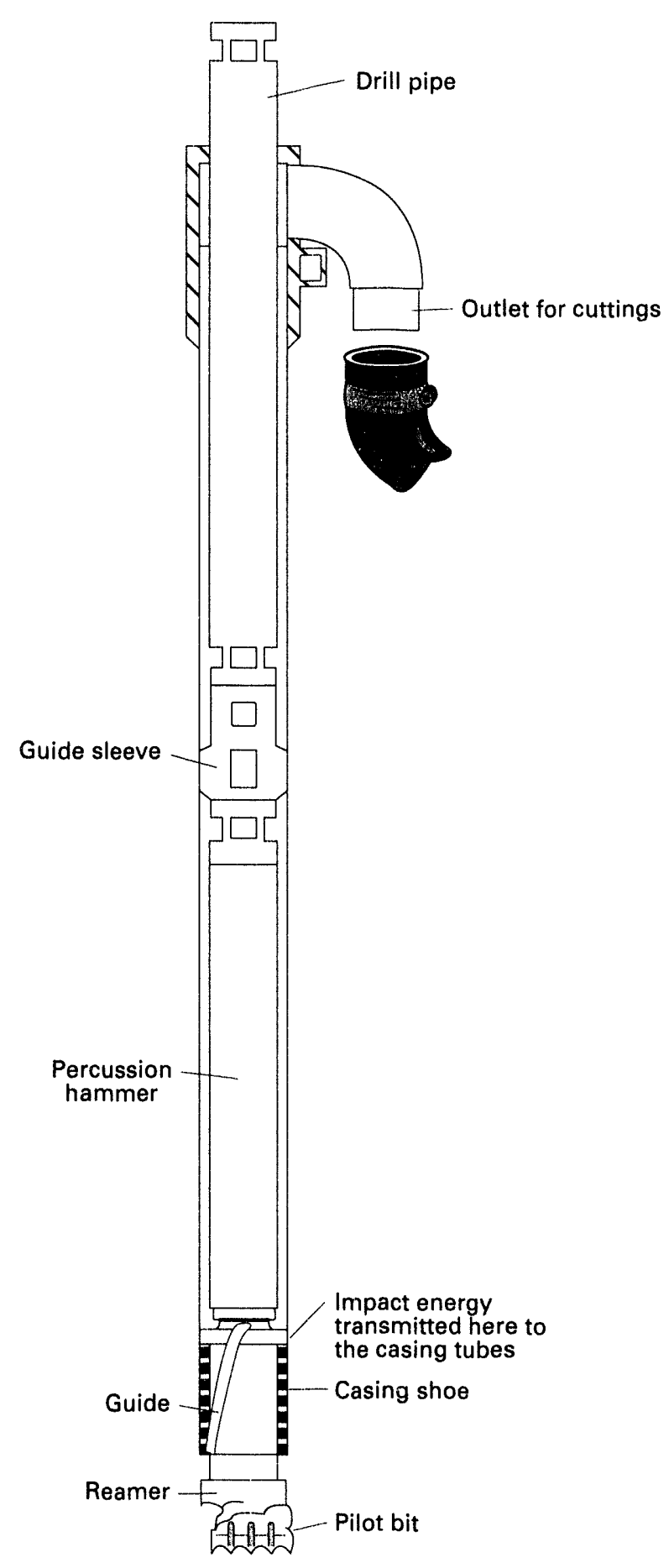

Figure 2. Drilling system used for test hole USW UZ-6s (from Hammermeister and others, 1985, p. 512). 
The casing for UZ-6s had a 194-mm O.D. and a 177-mm inside diameter (I.D.). Each casing section was $6.1-\mathrm{m}$ long. The drill hole was $212 \mathrm{~mm}$ in diameter. Test hole UZ-6s was drilled, cored, and cased to a depth of $120.7 \mathrm{~m}$ when the pilot bit almost separated from the casing shoe. Because the contact with the lower vitrophyre zone of the Tiva Canyon Member had been penetrated, coring continued to a total depth of $158.2 \mathrm{~m}$. Test hole UZ-6s then was continuously reamed and cased to a depth of $150.6 \mathrm{~m}$ when the pilot bit completely separated from the casing shoe. The bit was recovered; reaming and casing ceased at this depth. As the casing was being pulled out, it separated at a depth of $79.2 \mathrm{~m}$. Only the upper section was removed at this time. Between August 30, 1985, and September 6,1985, the upper section of the casing was reinserted, and the hole was cleaned out. The lower section of the casing was then hooked, and the upper and the lower sections of casing were removed.

\section{CORING METHODS}

A wireline, split-tube core barrel was used to obtain rotary cores from the hard, densely welded tuffs.
The core barrel had a 61-mm I.D. and was $1.52 \mathrm{~m}$ in length, modified by Norton Christensen, Inc., for air coring. Surface-set diamond bits were used to core the densely welded tuffs and tungsten-carbide, face-discharge bits were used to core nonwelded and bedded tuffs that were relatively soft and poorly sorted. These bits were a pilot-type that had staggered teeth. A total of $46.10 \mathrm{~m}$ was cored from UZ-6s with 84-percent recovery.

The drill rate for rotary coring in the different rock units penetrated by UZ-6s is shown in figure 3 . The densely welded tuffs penetrated by UZ-6s generally were cored at a rate of about 0.25 to about $0.50 \mathrm{~m} / \mathrm{hr}$. The coring rates in the nonwelded and bedded units generally ranged from about 1 to $10 \mathrm{~m} / \mathrm{hr}$.

\section{GEOLOGY AND LITHOLOGY}

The rocks penetrated by UZ-6s are of volcanic and volcanic-clastic origin. No alluvial-colluvial material was encountered in this test hole. A summary of the stratigraphic units penetrated is provided in table 1. Ash-flow and ash-fall tuffs, which comprise the Tiva Canyon Member, the unnamed bedded tuffs, and the

Table 1. Stratigraphic units penetrated by test hole USW UZ-6S

[Michael Chomack, U.S. Geological Survey, written commun., 1985]

\begin{tabular}{lcc}
\hline \multicolumn{1}{c}{ Goologic formation } & $\begin{array}{c}\text { Thickness of Intervals } \\
\text { (moters) }\end{array}$ & $\begin{array}{c}\text { Depth to bottom of Interval } \\
\text { (moters) }\end{array}$ \\
\hline $\begin{array}{l}\text { Paintbrush Tuff (Miocene age) } \\
\text { Tiva Canyon Member } \\
\text { (upper unit) }\end{array}$ & 116.4 & ${ }_{116.4}$ \\
$\begin{array}{l}\text { Tiva Canyon Member (lower } \\
\text { vitrophyre) }\end{array}$ & 7.9 & 1124.3 \\
$\begin{array}{l}\text { Tiva Canyon Member (shardy } \\
\text { base) }\end{array}$ & 6.9 & 131.2 \\
$\begin{array}{l}\text { Unnamed bedded turf } \\
\text { Topopah Spring Member (vitric } \\
\text { unit) }\end{array}$ & 9.0 & 140.2 \\
$\begin{array}{l}\text { Topopah Spring Member } \\
\text { (caprock) }\end{array}$ & 7.1 & 1147.3 \\
\hline Estimated contact & 10.9 & 158.2 \\
\hline
\end{tabular}




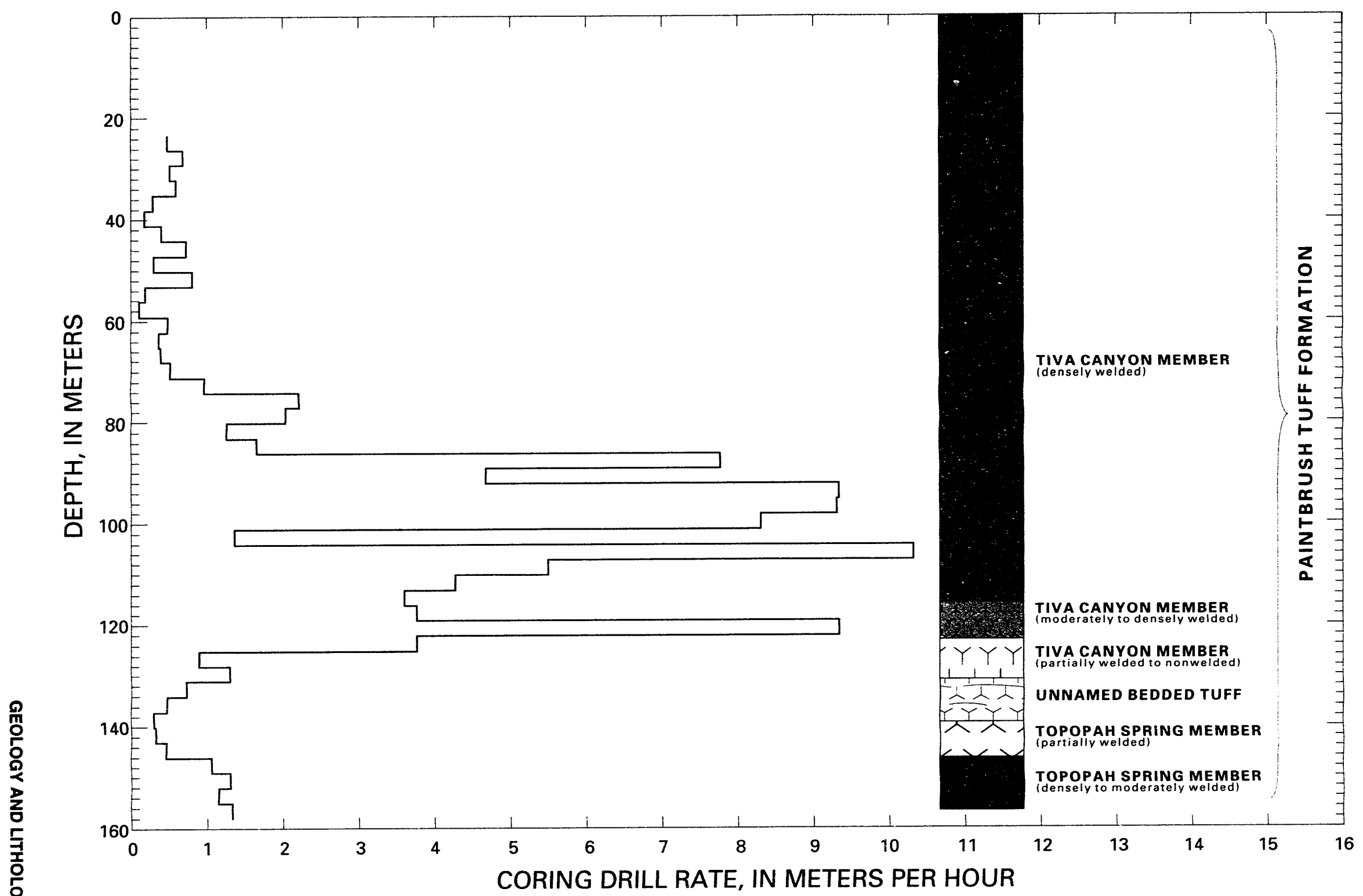

Figure 3. Rotary coring drill rate and degree of welding at test hole USW UZ-6s. 
Topopah Spring Member of the Paintbrush Tuff Formation of Miocene age, are the predominant rock types in this section. The tuffs exhibit various degrees of welding, ranging from nonwelded to densely welded. The upper unit of the Tiva Canyon Member of the Paintbrush Tuff consists of a devitrified tuff that is densely welded and underlain by a lower vitrophyre zone that is moderately to densely welded, which grades into a shardy base that is partially welded to nonwelded. The portion of the Topopah Spring Member of the Paintbrush Tuff penetrated in UZ-6s consists of a thin, partially welded upper vitric unit, which is underlain by a caprock that is moderately to densely welded.

\section{SAMPLE COLLECTION AND HANDLING}

Sample collection and handling followed approved YMP quality-assurance procedures. All procedures were designed to minimize the disturbance of the water content of the samples from the time the samples were removed from the test hole until gravimetric water-content and water-potential measurements were made.

\section{Drill Cuttings}

Drill cuttings were collected for the determination of a lithologic record as well as hydrologic properties. Cuttings returned to the surface through the casing during drilling were diverted through a flexible hose to a dry cyclone separator located nearby. After a prescribed interval of the test hole had been drilled, the gate valve on the bottom of the separator was opened, and the cuttings fell into the collection containers. The cyclone separator was emptied at each collection interval to avoid any mixing of samples. If the cuttings were moist, a hammer was used to loosen the cuttings off the inside walls of the separator. Drilling generally did not stop during sample collection.

A 0.5-L sample of cuttings was collected for lithologic description at the same time that 1 or $2 \mathrm{~L}$ of cuttings were collected at each sampling interval for laboratory measurements of water content and water potential. If the cuttings consisted mainly of finegrained material, $2 \mathrm{~L}$ were collected. The cuttings were placed in 1-L glass mason jars. These jars were capped immediately with air-tight lids, taken into the onsite laboratory as soon as possible, and placed inside a humidified glove box.

Drill cuttings from UZ-6s were collected at 0.6-m intervals from a depth of 2.1 to $150.3 \mathrm{~m}$. The drill cuttings were processed inside the humidified glove box. Coarse-particle-size fraction of drill cuttings from UZ-6s were used for water-content and water-potential measurements. If an insufficient volume of coarse cuttings was collected for water-content measurements and for water-potential measurements, fine- or composite-particle-size cuttings were used for the water-content measurements. Coarse samples were defined as those cuttings that would not pass through a screen that had about 1.6-mm openings, whereas fine samples were defined as those cuttings that would pass through this size opening. Samples taken directly from the jars were designated as composite samples. Coarse cuttings were always collected for water-potential measurements because only a small sample was necessary for testing. Samples for gravimetric water content were placed in preweighed $420-\mathrm{mL}$ moisture cans and immediately weighed. Samples for water-potential measurements were placed in small glass jars (approximately $120 \mathrm{~mL}$ or less), capped, taped, labeled, sealed in wax, and stored at room temperature (about 20 to $25^{\circ} \mathrm{C}$ ) until the measurements could be made.

\section{Rotary Core}

Test hole UZ-6s was continuously cored from 120.7 to $158.2 \mathrm{~m}$ before the hole was reamed and the casing set at a depth of $150.6 \mathrm{~m}$. A $0.61-\mathrm{m}$ core generally was collected from every $6.1-\mathrm{m}$ interval drilled in the moderately to densely welded tuffs in UZ-6s, beginning at a depth of 23.16 to $120.70 \mathrm{~m}$. After obtaining the $0.61-\mathrm{m}$ core, the hole was reamed and the 6.1-m-long casing inserted. In highly fractured zones of the densely welded tuff, shorter cores or no cores were occasionally collected due to poor recovery.

Cores from the partially welded, nonwelded, and bedded tuff units beginning at 120.70 to $158.19 \mathrm{~m}$ were obtained using a 1.52-m-long HWD4 core barrel with a split inner tube. The top one-half of the split inner tube was removed in the humidified glove box. The natural fractures of the core were described, and a preliminary lithologic description was made. For each 1.52-m-long core, a 91-mm-long segment of core from near the bottom and another from near the midsection of the core generally were removed for gravimetric water-content and water-potential measurements. If the core was highly fragmented, more samples were obtained for gravimetric water-content and water-potential measurements that did not require solid pieces of core; solid pieces of core were required, however, for other hydrologic testing. Whenever possible, one 1.52 -m-long core segment that was relatively unfragmented was taken from each one-half of the core for matric-potential measurements, and one additional 
91-mm-long core segment that was relatively unfragmented was taken for permeability-related tests.

Finally, a 91-mm-long section of core was selected from most core runs for the extraction and geochemical analysis of pore water (Mower and others, 1990). All core segments, except for those used for gravimetric water-content and water-potential measurements, were placed in split polyvinyl (PVC) liners, capped, taped, labeled, waxed, and stored at about 20 to $25^{\circ} \mathrm{C}$ for future hydrologic testing.

Core that was designated for gravimetric watercontent measurements was put in a preweighed moisture can. Core to be used for water-potential measurements was broken into small fragments inside a humidified glove box, placed in a $120-\mathrm{mL}$, or smaller, container, capped, taped, labeled, and waxed for later measurements. All cored intervals and recovered cores for UZ-6s are listed in table 2.

\section{SAMPLE TESTING PROCEDURES AND RESULTS}

\section{Gravimetric Water-Content Measurements}

Gravimetric water-content measurements were done onsite at the U.S. Geological Survey field laboratory, using standard gravimetric oven-drying methods (Gardner, 1965) following approved YMP qualityassurance procedures. Moisture cans of known weight were filled with drill cuttings or core and immediately weighed. These moisture cans were weighed again after baking in an oven at $105^{\circ} \mathrm{C}$ for a minimum of 18 hours. Gravimetric water content, in gram per gram, equals the water lost through drying, divided by the weight of the dried sample. Results of laboratory analyses for gravimetric water content for UZ-6s cuttings and core are listed in tables 3 and 4 . The depths of cuttings listed in table 3 represent the midpoints, or average depths, of the sample-collection intervals of the drill cuttings. Gravimetric water-content measurements of composite core samples and coarse-size fractions of drill cuttings for UZ-6s are shown in figure 4.

The gravimetric water content of the volcanic tuffs are related to the degree of welding. A summary of gravimetric water-content measurements of composite core samples related to geologic formation and degree of welding is listed in table 5. Only the core data for UZ-6s are tabulated because the cores are less disturbed than the drill cuttings and, therefore, are assumed to be more representative of in-situ hydrologic conditions. The densely welded part of the Tiva Canyon Member of the Paintbrush Tuff averaged
$0.027 \mathrm{~g} / \mathrm{g}$ for gravimetric water content, and the moderately to densely welded part averaged $0.054 \mathrm{~g} / \mathrm{g}$.

The partially to nonwelded part of the Tiva Canyon Member of the Paintbrush Tuff averaged $0.123 \mathrm{~g} / \mathrm{g}$. The unnamed bedded tuff unit had an average gravimetric water content of $0.106 \mathrm{~g} / \mathrm{g}$. The Topopah Spring Member of the Paintbrush Tuff is the deepest tuff unit penetrated; the gravimetric water content of the partially welded vitric subunit of this unit averaged $0.085 \mathrm{~g} / \mathrm{g}$, then decreased to an average of $0.027 \mathrm{~g} / \mathrm{g}$ in the densely to moderately welded caprock.

Test hole UZ-6s was continuously cored from the interval of 120.7 to $158.2 \mathrm{~m}$ before the hole was reamed. The gravimetric water content of cuttings from this interval averaged $0.058 \mathrm{~g} / \mathrm{g}$, which is lower than the gravimetric water content of core, which averaged $0.087 \mathrm{~g} / \mathrm{g}$.

After determination of the gravimetric water content, the dried core samples were placed in paper cartons and labeled. These samples were later tested by Holmes \& Narver Materials Testing Laboratory, Inc., at Mercury, Nev., for measurements of bulk density and grain density.

\section{Water-Potential Measurements}

Water potential is defined as the sum of matric and osmotic potentials. Water potentials were measured using a Richards' SC-10 thermocouple psychrometer and an NT-3 nanovoltmeter. The SC-10 psychrometer is a stationary device that has ten rotating chambers into which sample cups are placed. The Richards' method (Richards and Ogata, 1958) is based on dipping a ceramic bead attached at the thermocouple junction into distilled water, then letting it reach vapor equilibrium while positioned over a sample. The ceramic bead is located inside the SC-10 psychrometer. The rate of evaporation of distilled water on the ceramic bead is measured as voltage-output readings, generally for 10 minutes, on the nanovoltmeter while vapor equilibrium occurs. Drier samples of more than approximately -25 bars generally reach equilibrium in less than 10 minutes; moister samples of approximately -25 bars or less generally require 10 minutes. Voltage outputs are recorded at 1-minute intervals.

Two SC-10 psychrometers were used for measuring water potentials of rock samples. Sample cups were placed in the ten rotating chambers of the SC-10 psychrometer. Three of the ten sample cups (cups 1 through 3) were lined with filter paper and wetted with three of six calibration standards of known molality; six of the sample cups (cups 4 through 9) were filled with cuttings or core samples; the last sample cup 
Table 2. Rotary-core record for test hole USW UZ-6s

[A, gravimetric water-content, water-potential, bulk-density, and grain-density measurements; B, matric-potential measurements; C, D, E, permeability-related and miscellaneous measurements; - , no data. The core intervals and lengths were measured to the nearest 0.1 foot, or approximately plus or minus 0.015 meter; core intervals are listed to plus or minus 0.005 meter for convenience and as a result of conversion from inch-pound units.]

\begin{tabular}{|c|c|c|c|c|}
\hline Core run number' & $\begin{array}{l}\text { Cored Interval } \\
\text { (moters) }\end{array}$ & $\begin{array}{l}\text { Cored length } \\
\text { (meters) }\end{array}$ & $\begin{array}{l}\text { Core recovered } \\
\text { (meters) }\end{array}$ & Laboratory tests \\
\hline 1 & $23.16-23.77$ & 0.61 & 0.49 & $\overline{A D E}$ \\
\hline 2 & $29.26-29.87$ & 0.61 & 0.61 & ACE \\
\hline 3 & $35.36-35.96$ & 0.60 & 0.61 & ACDE \\
\hline 4 & $41.45-42.06$ & 0.61 & 0.61 & A D E \\
\hline 5 & $47.55-48.16$ & 0.61 & 0.61 & $A C D E$ \\
\hline 6 & $53.64-53.95$ & 0.31 & 0.30 & $A C D E$ \\
\hline 7 & $59.74-60.35$ & 0.61 & 0.61 & ADE \\
\hline 8 & $65.83-66.44$ & 0.61 & 0.61 & A B CDE \\
\hline 9 & $78.02-78.63$ & 0.61 & 0.61 & ACDE \\
\hline 10 & $84.12-84.73$ & 0.61 & 0.61 & ACDE \\
\hline 11 & $90.22-90.52$ & 0.30 & 0.27 & $A C D$ \\
\hline 12 & $90.52-90.58$ & 0.06 & 0.00 & -- \\
\hline 13 & $96.31-96.92$ & 0.61 & 0.58 & ACDE \\
\hline 14 & $102.41-103.02$ & 0.61 & 0.55 & $A C D E$ \\
\hline 15 & $108.50-109.11$ & 0.61 & 0.43 & A DE \\
\hline 16 & $114.60-115.21$ & 0.61 & 0.53 & A D E \\
\hline 17 & $120.69-122.22$ & 1.53 & 1.52 & A B C DE \\
\hline 18 & $122.22-123.74$ & 1.52 & 1.52 & A B CDE \\
\hline 19 & $123.74-125.27$ & 1.53 & 1.52 & A B CDE \\
\hline 20 & $125.27-126.79$ & 1.52 & 1.52 & A B C DE \\
\hline 21 & $126.79-128.31$ & 1.52 & 1.52 & A B C DE \\
\hline 22 & $128.31-129.84$ & 1.53 & 1.22 & A E \\
\hline 23 & $129.84-130.75$ & 0.91 & 0.61 & A B CD \\
\hline 24 & $130.75-131.97$ & 1.22 & 1.52 & A B C DE \\
\hline 25 & $131.97-133.50$ & 1.53 & 1.22 & A B CDE \\
\hline 26 & $133.50-134.72$ & 1.22 & 1.52 & A B C DE \\
\hline 27 & $134.72-136.24$ & 1.52 & 0.76 & A B D E \\
\hline 28 & $136.24-137.76$ & 1.52 & 0.55 & A B D E \\
\hline 29 & $137.76-139.29$ & 1.53 & 1.28 & ACDE \\
\hline 30 & $139.29-140.81$ & 1.52 & 1.07 & A BCDE \\
\hline 31 & $140.81-142.03$ & 1.22 & 0.98 & A B D E \\
\hline 32 & $142.03-143.55$ & 1.52 & 0.64 & A B CDE \\
\hline 33 & $143.55-144.77$ & 1.22 & 0.46 & A DE \\
\hline 34 & $144.77-146.30$ & 1.53 & 0.00 & -- \\
\hline 35 & $146.30-146.60$ & 0.30 & 0.06 & $\mathbf{A}$ \\
\hline 36 & $146.60-147.21$ & 0.61 & 0.61 & A B D E \\
\hline 37 & $147.21-148.43$ & 1.22 & 1.04 & A BCDE \\
\hline 38 & $148.43-149.19$ & 0.76 & 0.64 & A B D E \\
\hline 39 & $149.19-149.50$ & 0.31 & 0.35 & A D E \\
\hline 40 & $149.50-150.87$ & 1.37 & 1.37 & A B C DE \\
\hline 41 & $150.87-152.39$ & 1.52 & 1.52 & A B C DE \\
\hline
\end{tabular}


Tablo 2. Rotary-core record for test hole USW UZ-68--Continued

\begin{tabular}{ccccc}
\hline Core nun number' & $\begin{array}{c}\text { Cored interval } \\
\text { (meters) }\end{array}$ & $\begin{array}{c}\text { Cored length } \\
\text { (meters) }\end{array}$ & $\begin{array}{c}\text { Core recovered } \\
\text { (moters) }\end{array}$ & Laboratory teate \\
\hline 42 & $152.39-153.92$ & 1.53 & 1.07 & A B C D E \\
43 & $153.92-155.14$ & 1.22 & 1.52 & A B C D E \\
44 & $155.14-156.66$ & 1.52 & 1.52 & A B C D E \\
45 & $156.66-158.18$ & 1.52 & 1.52 & A B C D E \\
\hline
\end{tabular}

Tore runs 1-16 were drilled in the upper unit of the Tiva Canyon Member, a densely velded unit; cores were selectively collected from this unit.

(cup 10) was filled with distilled water. The calibration standards were measured concurrently with the cuttings or core samples to compensate for the zero drift of the nanovoltmeter amplifier due to change in temperature. The calibration standards used, and their approximate kilopascal equivalents, were: $0.02 \mathrm{~m}$ (molality), $-100 \mathrm{Kpa} ; 0.05 m,-230 \mathrm{Kpa} ; 0.1 m,-460 \mathrm{kPa} ; 0.4 \mathrm{~m}$, $-1,800 \mathrm{kPa} ; 0.8 m,-3,700 \mathrm{kPa}$; and $1.5 m,-7,200 \mathrm{kPa}$.

The same calibration standards were not used for all cuttings and core samples. As much as possible, samples that had similar water contents, based on gravimetric water-content measurements, were processed together. Three calibration standards then were selected within a range that spanned the expected possible water-potential range of the six cuttings or core samples in the SC-10 psychrometer.

The SC-10 psychrometer sample cups are loaded with calibration standards and rock samples in a humidified glove box to minimize evaporation. The ten sample cups then are placed into the ten sample chambers of the SC-10 psychrometer. Samples in the SC-10 psychrometer are allowed to equilibrate for a minimum of 30 minutes before any measurements are made. All measurements were made inside the humidified glove box, at a relatively constant room temperature, generally at 20 to $25^{\circ} \mathrm{C}$.

The procedure for taking water-potential measurements begins by first taking a temperature reading from the nanovoltmeter of the calibration standard in the first chamber (cup 1). The NT-3 nanovoltmeter, by Decagon Devices, is designed to measure both resistance and temperature. The sample cups in the chambers are rotated, and the ceramic bead of the thermocouple is wetted in the distilled water (cup 10). The samples are rotated back until the thermocouple is located again over the first chamber (cup 1). As long as
10 minutes are allowed for vapor equilibrium to occur; voltage outputs are recorded at 1-minute intervals. Another temperature reading is then taken. The calibration chambers are rotated, and the ceramic bead is wetted again in the distilled water (cup 10). The calibration chambers are then rotated until the thermocouple is located over the second chamber (cup 2).

Voltage-output readings are again taken at 1-minute intervals for as long as 10 minutes. This continues until voltage-output readings have been recorded for all the calibration standards and the rock samples (cups 1 through 9).

At the end of 10 minutes of recording the voltage outputs, an averaged representative voltage-output reading is selected based on the evidence of a plateau. This plateau in voltage-output readings occurs when the system is in equilibrium, and little change is evident in the voltage-output readings. Once sufficient evaporation has occurred, the meniscus of the water on the ceramic bead loses its cohesiveness, evaporation proceeds more quickly, and the voltage-output readings begin dropping off rapidly. For moister samples of more than $-2,000 \mathrm{kPa}$, the plateaus tend to be more evident during the last 5 minutes of the voltage-output readings and tend to last longer; for very moist samples of more than $-400 \mathrm{kPa}$, the plateau drop-off may not be noted in the 10 minutes of voltage-output readings. For drier samples of less than $-5,000 \mathrm{kPa}$, the plateaus tend to occur during the first 5 minutes of voltage-output readings and may only last for a couple of minutes before the readings begin dropping off rapidly. Very dry samples with readings of less than $-10,000 \mathrm{kPa}$ generally level off sufficiently fast that the voltage-output reading recorded at 1 minute is considered to be the plateau. 
Table 3. Results of laboratory analyses for gravimetric water content and water potential of coarse drill cuttings from test hole USW UZ-6s

$[-$, no data $]$

\begin{tabular}{|c|c|c|}
\hline $\begin{array}{l}\text { Depth of midpoint of samplo } \\
\text { (moters) }\end{array}$ & $\begin{array}{l}\text { Gravimetric water content } \\
\text { (gram per gram) }\end{array}$ & $\begin{array}{l}\text { Water potential } \\
\text { (kllopascals) }\end{array}$ \\
\hline 2.1 & 0.026 & -790 \\
\hline 2.7 & 0.028 & -630 \\
\hline 3.4 & -- & -- \\
\hline 4.0 & 0.021 & -670 \\
\hline 4.6 & 0.004 & $-25,000$ \\
\hline 5.2 & 0.012 & $-8,200$ \\
\hline 5.8 & 0.020 & $-2,400$ \\
\hline 6.4 & 0.013 & $-4,700$ \\
\hline 7.0 & 0.015 & $-2,600$ \\
\hline 7.6 & 0.025 & $-1,100$ \\
\hline 8.2 & 0.018 & $-2,700$ \\
\hline 8.8 & 0.026 & $-2,100$ \\
\hline 9.4 & 0.033 & -940 \\
\hline 10.1 & 0.042 & -420 \\
\hline 10.5 & 0.032 & -750 \\
\hline 10.8 & 0.022 & $-2,600$ \\
\hline 11.3 & 0.025 & $-1,600$ \\
\hline 11.9 & 0.030 & -740 \\
\hline 12.5 & 0.031 & -710 \\
\hline 13.1 & 0.031 & -520 \\
\hline 13.7 & 0.028 & -390 \\
\hline 14.3 & 0.044 & -390 \\
\hline 14.9 & 0.052 & -570 \\
\hline 15.5 & 0.037 & $-1,300$ \\
\hline 16.2 & 0.042 & -790 \\
\hline 16.8 & 0.039 & $-8,300$ \\
\hline 17.2 & 0.023 & $-2,900$ \\
\hline 17.7 & 0.024 & $-3,400$ \\
\hline 18.3 & 0.027 & $-3,000$ \\
\hline 18.7 & 0.030 & $-2,100$ \\
\hline 19.2 & 0.034 & $-1,300$ \\
\hline 19.8 & 0.031 & $-2,400$ \\
\hline 20.4 & 0.030 & $-2,600$ \\
\hline 21.0 & 0.029 & $-2,700$ \\
\hline 21.6 & 0.029 & $-2,300$ \\
\hline 22.3 & 0.028 & $-3,800$ \\
\hline 22.9 & 0.029 & $-2,800$ \\
\hline 23.5 & 0.022 & $-5,800$ \\
\hline 24.1 & 0.027 & $-2,500$ \\
\hline 24.7 & 0.033 & $-1,400$ \\
\hline 25.3 & 0.036 & -950 \\
\hline 25.9 & 0.036 & $-1,500$ \\
\hline
\end{tabular}


Table 3. Results of laboratory analyses for gravimetric water content and water potential of coarse drill cuttings from test hole USW UZ-6s--Continued

\begin{tabular}{|c|c|c|}
\hline $\begin{array}{l}\text { Depth of midpoint of sample } \\
\text { (meters) }\end{array}$ & $\begin{array}{l}\text { Gravimetric water content } \\
\text { (gram per gram) }\end{array}$ & $\begin{array}{l}\text { Water potential } \\
\text { (kilopascals) }\end{array}$ \\
\hline 26.5 & 0.017 & -780 \\
\hline 27.1 & 0.030 & $-1,000$ \\
\hline 27.7 & 0.033 & $-1,300$ \\
\hline 28.3 & 0.028 & $-1,600$ \\
\hline 29.0 & 0.030 & $-1,200$ \\
\hline 29.6 & 0.031 & $-2,900$ \\
\hline 30.2 & 0.037 & $-1,100$ \\
\hline 30.8 & 0.035 & $-1,600$ \\
\hline 31.4 & 0.040 & -820 \\
\hline 32.0 & 0.045 & -950 \\
\hline 32.6 & 0.049 & -720 \\
\hline 33.2 & 0.046 & -760 \\
\hline 33.8 & 0.044 & -900 \\
\hline 34.4 & 0.047 & -980 \\
\hline 35.1 & 0.048 & -650 \\
\hline 35.7 & 0.048 & -660 \\
\hline 36.3 & 0.049 & -630 \\
\hline 36.9 & 0.044 & -740 \\
\hline 37.5 & 0.044 & -710 \\
\hline 38.1 & 0.043 & -800 \\
\hline 38.7 & 0.041 & -810 \\
\hline 39.3 & 0.044 & -650 \\
\hline 39.9 & 0.043 & -710 \\
\hline 40.5 & 0.041 & -790 \\
\hline 41.1 & 0.043 & -610 \\
\hline 41.8 & 0.028 & $-3,000$ \\
\hline 42.4 & 0.027 & $-3,900$ \\
\hline 43.3 & 0.031 & $-1,800$ \\
\hline 44.2 & 0.033 & $-1,100$ \\
\hline 44.8 & 0.034 & $-1,200$ \\
\hline 45.4 & 0.034 & $-1,300$ \\
\hline 46.0 & 0.029 & $-2,900$ \\
\hline 46.6 & 0.025 & $-4,100$ \\
\hline 47.2 & 0.031 & $-1,900$ \\
\hline 47.9 & 0.017 & $-6,700$ \\
\hline 48.5 & 0.021 & $-2,300$ \\
\hline 49.1 & 0.013 & $-15,000$ \\
\hline 49.6 & -- & $-8,400$ \\
\hline 50.2 & 0.029 & $-7,500$ \\
\hline 50.9 & 0.035 & $-1,300$ \\
\hline 51.5 & 0.032 & $-1,600$ \\
\hline 52.1 & 0.031 & $-2,600$ \\
\hline 52.7 & 0.029 & $-3,100$ \\
\hline
\end{tabular}


Table 3. Results of laboratory analyses for gravimetric water content and water potentiai of coarse drill cuttings from test hole USW UZ-6s--Continued

\begin{tabular}{|c|c|c|}
\hline $\begin{array}{l}\text { Depth of midpolnt of sample } \\
\text { (moters) }\end{array}$ & $\begin{array}{c}\text { Gravimetric water content } \\
\text { (gram per gram) }\end{array}$ & $\begin{array}{l}\text { Water potential } \\
\text { (kliopascals) }\end{array}$ \\
\hline 53.3 & 0.033 & $-1,400$ \\
\hline 53.9 & 0.019 & $-5,700$ \\
\hline 54.6 & 0.025 & $-4,300$ \\
\hline 55.2 & 0.025 & $-4,100$ \\
\hline 55.8 & 0.028 & $-2,800$ \\
\hline 56.4 & 0.025 & $-3,600$ \\
\hline 57.0 & 0.027 & $-3,100$ \\
\hline 57.6 & 0.033 & $-2,000$ \\
\hline 58.2 & 0.035 & $-1,900$ \\
\hline 58.8 & 0.033 & $-2,900$ \\
\hline 59.4 & 0.033 & $-2,300$ \\
\hline 60.0 & 0.017 & $-5,900$ \\
\hline 60.7 & 0.019 & $-5,200$ \\
\hline 61.3 & 0.028 & $-3,900$ \\
\hline 61.9 & 0.027 & $-4,500$ \\
\hline 62.5 & 0.028 & $-4,200$ \\
\hline 63.1 & 0.034 & $-2,000$ \\
\hline 63.7 & 0.025 & $-5,800$ \\
\hline 64.3 & 0.029 & $-4,700$ \\
\hline 64.9 & 0.028 & $-4,400$ \\
\hline 65.5 & 0.027 & $-2,800$ \\
\hline 66.1 & 0.022 & $-6,500$ \\
\hline 66.8 & 0.026 & $-3,200$ \\
\hline 67.4 & 0.025 & $-3,800$ \\
\hline 68.0 & 0.025 & $-3,600$ \\
\hline 68.6 & 0.027 & $-2,900$ \\
\hline 69.2 & 0.024 & $-3,400$ \\
\hline 69.8 & 0.027 & $-2,900$ \\
\hline 70.4 & 0.023 & $-9,000$ \\
\hline 71.0 & 0.026 & $-4,400$ \\
\hline 71.6 & 0.026 & $-3,200$ \\
\hline 72.2 & 0.026 & $-4,000$ \\
\hline 72.8 & 0.026 & $-3,700$ \\
\hline 73.5 & 0.032 & $-1,300$ \\
\hline 74.1 & 0.036 & -670 \\
\hline 74.7 & 0.034 & -830 \\
\hline 75.3 & 0.033 & $-1,200$ \\
\hline 75.9 & 0.030 & $-1,300$ \\
\hline 76.5 & 0.027 & $-2,500$ \\
\hline 77.1 & 0.028 & $-2,000$ \\
\hline 77.7 & 0.025 & $-4,100$ \\
\hline 78.3 & 0.016 & $-8,200$ \\
\hline 78.9 & 0.017 & $-9,200$ \\
\hline
\end{tabular}


Table 3. Results of laboratory analyses for gravimetric water content and water potential of coarse drill cuttings from test hole USW UZ-6s--Continued

\begin{tabular}{|c|c|c|}
\hline $\begin{array}{l}\text { Depth of midpolnt of sample } \\
\text { (motors) }\end{array}$ & $\begin{array}{l}\text { Gravimetrlc water content } \\
\text { (gram per gram) }\end{array}$ & $\begin{array}{l}\text { Water potential } \\
\text { (kilopascals) }\end{array}$ \\
\hline 79.6 & 0.018 & $-10,000$ \\
\hline 80.2 & 0.019 & $-9,800$ \\
\hline 80.8 & 0.020 & $-8,500$ \\
\hline 81.4 & 0.019 & $-6,600$ \\
\hline 82.0 & 0.019 & $-9,600$ \\
\hline 82.6 & 0.023 & $-6,100$ \\
\hline 83.2 & 0.021 & $-8,200$ \\
\hline 83.8 & 0.018 & $-9,700$ \\
\hline 84.4 & 0.011 & $-16,000$ \\
\hline 85.0 & 0.012 & $-9,500$ \\
\hline 85.6 & 0.016 & $-8,900$ \\
\hline 86.3 & 0.020 & $-5,100$ \\
\hline 86.9 & 0.024 & $-3,800$ \\
\hline 87.5 & 0.023 & $-5,400$ \\
\hline 88.1 & 0.023 & $-6,700$ \\
\hline 88.7 & 0.024 & $-4,700$ \\
\hline 89.3 & 0.024 & $-5,600$ \\
\hline 89.9 & 0.023 & $-6,900$ \\
\hline 90.5 & 0.015 & $-9,900$ \\
\hline 91.1 & 0.016 & $-9,100$ \\
\hline 91.7 & 0.017 & $-6,900$ \\
\hline 92.4 & 0.017 & $-8,300$ \\
\hline 93.0 & 0.016 & $-9,500$ \\
\hline 93.6 & 0.018 & $-5,000$ \\
\hline 94.2 & 0.017 & $-6,700$ \\
\hline 94.8 & 0.019 & $-8,100$ \\
\hline 95.4 & 0.017 & $-6,800$ \\
\hline 96.0 & 0.018 & $-5,300$ \\
\hline 96.6 & 0.015 & $-7,900$ \\
\hline 97.2 & 0.015 & $-11,000$ \\
\hline 97.8 & 0.015 & $-14,000$ \\
\hline 98.5 & 0.019 & $-12,000$ \\
\hline 99.1 & 0.018 & $-12,000$ \\
\hline 99.7 & 0.018 & $-12,000$ \\
\hline 100.3 & 0.017 & $-12,000$ \\
\hline 100.9 & 0.018 & $-9,100$ \\
\hline 101.5 & 0.017 & $-11,000$ \\
\hline 102.1 & 0.017 & $-12,000$ \\
\hline 102.7 & 0.013 & $-21,000$ \\
\hline 103.3 & 0.014 & $-15,000$ \\
\hline 103.9 & 0.008 & $-24,000$ \\
\hline 104.5 & 0.006 & $-30,000$ \\
\hline 105.2 & 0.012 & $-18,000$ \\
\hline
\end{tabular}


Table 3. Results of laboratory analyses for gravimetric water content and water potential of coarse drill cuttings from test hole USW UZ-6s--Continued

\begin{tabular}{|c|c|c|}
\hline $\begin{array}{l}\text { Depth of midpolnt of sample } \\
\text { (meters) }\end{array}$ & $\begin{array}{c}\text { Gravimetrlc water content } \\
\text { (gram per gram) }\end{array}$ & $\begin{array}{l}\text { Water potentlal } \\
\text { (kllopascais) }\end{array}$ \\
\hline 105.8 & 0.011 & $-16,000$ \\
\hline 106.4 & 0.011 & $-23,000$ \\
\hline 107.0 & 0.011 & $-19,000$ \\
\hline 107.6 & 0.009 & $-37,000$ \\
\hline 108.2 & 0.005 & $-42,000$ \\
\hline 108.8 & 0.005 & $-49,000$ \\
\hline 109.4 & 0.007 & $-43,000$ \\
\hline 110.0 & 0.010 & $-35,000$ \\
\hline 110.6 & 0.013 & $-21,000$ \\
\hline 111.3 & 0.011 & $-15,000$ \\
\hline 111.9 & ${ }^{1} 0.005$ & $-30,000$ \\
\hline 112.5 & 0.012 & $-20,000$ \\
\hline 113.1 & 0.012 & $-18,000$ \\
\hline 113.7 & 0.010 & $-25,000$ \\
\hline 114.3 & 0.012 & $-19,000$ \\
\hline 114.9 & 0.012 & $-18,000$ \\
\hline 115.5 & 0.010 & $-27,000$ \\
\hline 116.1 & 0.014 & $-23,000$ \\
\hline 116.7 & 0.013 & $-31,000$ \\
\hline 117.3 & 0.011 & $-32,000$ \\
\hline 118.0 & 0.009 & $-27,000$ \\
\hline 118.6 & 0.013 & $-47,000$ \\
\hline 119.2 & 0.011 & $-54,000$ \\
\hline 119.8 & 0.009 & $-52,000$ \\
\hline 120.4 & 0.010 & $-47,000$ \\
\hline 121.0 & - & -- \\
\hline 121.6 & 0.082 & $-31,000$ \\
\hline 122.2 & -- & -- \\
\hline 122.8 & 0.068 & $-27,000$ \\
\hline 123.4 & 0.052 & $-31,000$ \\
\hline 124.1 & 0.040 & $-42,000$ \\
\hline 124.7 & 0.040 & $-38,000$ \\
\hline 125.3 & 0.050 & $-33,000$ \\
\hline 125.9 & 0.074 & $-23,000$ \\
\hline 126.5 & 0.080 & $-22,000$ \\
\hline 127.1 & 0.088 & $-18,000$ \\
\hline 127.7 & 0.093 & $-17,000$ \\
\hline 128.3 & 0.070 & $-16,000$ \\
\hline 128.9 & 0.070 & $-12,000$ \\
\hline 129.5 & 0.060 & $-41,000$ \\
\hline 130.1 & 0.068 & $-36,000$ \\
\hline 130.8 & 0.073 & $-80,000$ \\
\hline 131.4 & 0.073 & $-55,000$ \\
\hline
\end{tabular}


Table 3. Resulis of laboratory analyses for gravimetric water content and water potential of coarse drill cuttings from test hole USW UZ-6s--Continued

\begin{tabular}{|c|c|c|}
\hline $\begin{array}{c}\text { Depth of midpoint of sample } \\
\text { (meters) }\end{array}$ & $\begin{array}{c}\text { Gravimetric water content } \\
\text { (gram per gram) }\end{array}$ & $\begin{array}{l}\text { Water potential } \\
\text { (kilopascals) }\end{array}$ \\
\hline 132.0 & 0.166 & $-5,600$ \\
\hline 132.6 & 0.124 & $-9,100$ \\
\hline 133.2 & 0.082 & $-7,000$ \\
\hline 133.8 & 0.055 & $-5,600$ \\
\hline 134.4 & 0.101 & $-16,000$ \\
\hline 135.0 & 0.096 & $-3,900$ \\
\hline 135.6 & 0.102 & $-1,300$ \\
\hline 136.2 & 0.074 & $-8,500$ \\
\hline 136.9 & 0.082 & $-23,000$ \\
\hline 137.5 & 0.070 & $-14,000$ \\
\hline 138.1 & 0.063 & $-59,000$ \\
\hline 138.7 & - & $-91,000$ \\
\hline 139.3 & ${ }^{2} 0.007$ & $-45,000$ \\
\hline 139.9 & 0.010 & $-64,000$ \\
\hline 140.5 & 0.064 & $-57,000$ \\
\hline 141.1 & 0.050 & $-44,000$ \\
\hline 141.7 & 0.092 & $-22,000$ \\
\hline 142.3 & 0.081 & $-24,000$ \\
\hline 143.0 & 0.081 & $-13,000$ \\
\hline 143.6 & 0.027 & $-39,000$ \\
\hline 144.2 & 0.027 & $-57,000$ \\
\hline 144.8 & 0.009 & $-68,000$ \\
\hline 145.4 & 0.008 & $-80,000$ \\
\hline 146.0 & 0.017 & $-66,000$ \\
\hline 146.6 & 0.025 & $-69,000$ \\
\hline 147.2 & 0.030 & $-73,000$ \\
\hline 147.8 & 0.024 & $-40,000$ \\
\hline 148.4 & 0.009 & $-54,000$ \\
\hline${ }^{2} 149.0$ & 0.011 & $-51,000$ \\
\hline 149.7 & 0.009 & $-57,000$ \\
\hline 150.3 & 0.008 & $-54,000$ \\
\hline
\end{tabular}

\footnotetext{
${ }^{2}$ Composite drill cuttings
} 
Table 4. Results of laboratory analyses for gravimetric water content and water potential of composite core samples from test hole USW UZ-6s

$[-$, indicates no data $]$

\begin{tabular}{|c|c|c|}
\hline $\begin{array}{l}\text { Depth interval } \\
\text { (moters) }\end{array}$ & $\begin{array}{l}\text { Gravimetric water content } \\
\text { (gram per gram) }\end{array}$ & $\begin{array}{l}\text { Water potential } \\
\text { (kllopaccals) }\end{array}$ \\
\hline $23.26-23.32$ & 0.033 & $-1,500$ \\
\hline $23.32-23.41$ & 0.032 & $-1,500$ \\
\hline $29.41-29.50$ & 0.034 & $-1,000$ \\
\hline $35.36-35.96$ & 0.040 & $-1,100$ \\
\hline $41.45-41.57$ & 0.034 & $-3,100$ \\
\hline $41.97-42.06$ & 0.035 & $-3,800$ \\
\hline $48.01-48.16$ & 0.030 & $-4,900$ \\
\hline $53.77-53.84$ & 0.034 & $-5,400$ \\
\hline $60.26-60.35$ & 0.026 & $-3,500$ \\
\hline $66.08-66.17$ & 0.031 & $-5,200$ \\
\hline $78.02-78.14$ & 0.019 & $-7,700$ \\
\hline $84.12-84.73$ & 0.022 & $-6,100$ \\
\hline $90.22-90.49$ & 0.018 & $-13,000$ \\
\hline $96.71-96.90$ & 0.022 & $-11,000$ \\
\hline $102.82-102.96$ & 0.019 & $-18,000$ \\
\hline $108.72-108.81$ & 0.017 & $-16,000$ \\
\hline $114.60-114.73$ & 0.014 & $-20,000$ \\
\hline $120.93-121.10$ & 0.040 & $-7,900$ \\
\hline $122.53-122.62$ & 0.059 & $-3,600$ \\
\hline $122.93-122.99$ & 0.050 & $-9,300$ \\
\hline $123.84-123.93$ & 0.068 & $-5,900$ \\
\hline $124.45-124.54$ & 0.103 & $-7,800$ \\
\hline $125.27-125.39$ & 0.140 & -710 \\
\hline $126.13-126.22$ & 0.109 & $-3,000$ \\
\hline $127.10-127.19$ & 0.160 & -720 \\
\hline $127.86-127.96$ & 0.136 & -580 \\
\hline $128.32-128.44$ & 0.126 & -580 \\
\hline $128.93-129.02$ & 0.120 & -580 \\
\hline $129.84-130.12$ & 0.114 & -550 \\
\hline $130.58-130.67$ & 0.098 & -500 \\
\hline $131.37-131.46$ & 0.205 & -530 \\
\hline $131.98-132.10$ & 0.076 & -480 \\
\hline $132.47-132.59$ & 0.094 & -480 \\
\hline $133.29-133.41$ & 0.104 & -600 \\
\hline $133.84-133.96$ & 0.119 & -410 \\
\hline $134.84-134.97$ & 0.149 & -360 \\
\hline $135.39-135.48$ & 0.107 & -320 \\
\hline 136.61-136.79 & 0.058 & -310 \\
\hline $137.95-138.07$ & 0.050 & -280 \\
\hline $138.47-138.59$ & 0.057 & -280 \\
\hline 139.39-139.48 & 0.143 & -780 \\
\hline $139.78-139.90$ & 0.107 & -960 \\
\hline
\end{tabular}


Table 4. Results of laboratory analyses for gravimetric water content and water potential of composite core samples from test hole USW UZ-6s--Continued

\begin{tabular}{|c|c|c|}
\hline $\begin{array}{l}\text { Depth Interval } \\
\text { (moters) }\end{array}$ & $\begin{array}{l}\text { Gravimetric water content } \\
\text { (gram per gram) }\end{array}$ & $\begin{array}{l}\text { Water potential } \\
\text { (kllopascals) }\end{array}$ \\
\hline $140.94-141.06$ & 0.081 & $-1,200$ \\
\hline $141.61-141.70$ & 0.209 & -520 \\
\hline $142.19-142.28$ & 0.077 & -800 \\
\hline $143.90-144.02$ & 0.047 & $-1,300$ \\
\hline $146.30-146.36$ & 0.062 & -570 \\
\hline $146.97-147.16$ & 0.032 & -560 \\
\hline $147.34-147.46$ & 0.010 & $-5,600$ \\
\hline $148.10-148.19$ & 0.020 & -940 \\
\hline $148.44-148.56$ & 0.018 & $-1,100$ \\
\hline $148.96-149.08$ & 0.016 & $-9,2 w$ \\
\hline $149.15-149.29$ & 0.019 & $-12,000$ \\
\hline $149.50-149.60$ & 0.028 & $-2,000$ \\
\hline $150.75-150.88$ & 0.015 & $-9,500$ \\
\hline $150.88-151.06$ & 0.026 & $-8,100$ \\
\hline $151.97-152.03$ & 0.032 & $-1,700$ \\
\hline $152.40-152.55$ & 0.031 & $-1,400$ \\
\hline $153.25-153.31$ & 0.034 & -650 \\
\hline $153.77-153.92$ & 0.031 & $-1,200$ \\
\hline $155.05-155.14$ & 0.035 & -580 \\
\hline $155.36-155.48$ & 0.034 & -520 \\
\hline $156.09-156.18$ & 0.036 & -700 \\
\hline $157.31-157.46$ & 0.040 & $-1,100$ \\
\hline $157.76-157.86$ & 0.038 & -760 \\
\hline
\end{tabular}




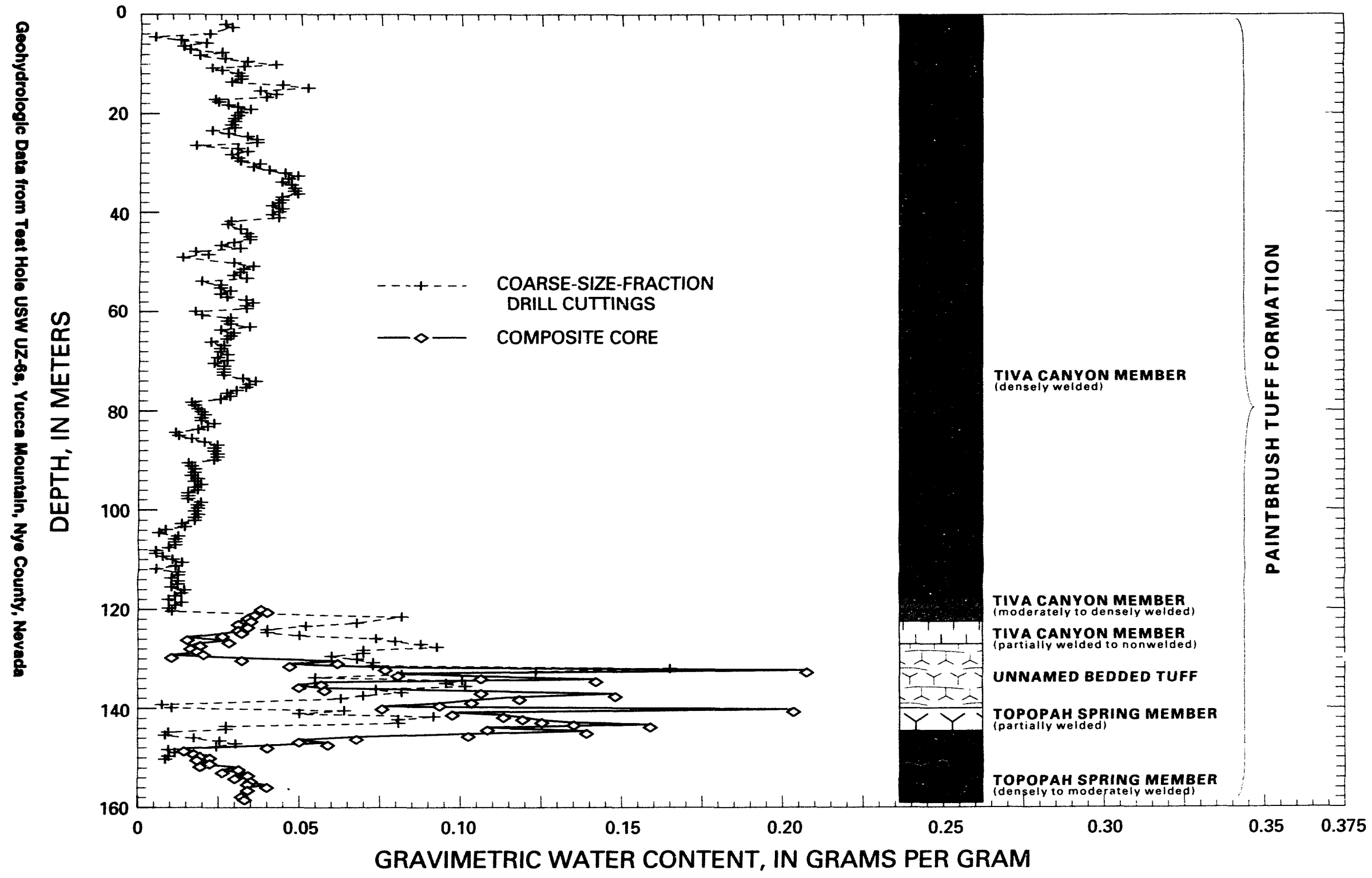

Figure 4. Gravimetric water-content measurements from coarse-size fraction drill cuttings and composite core from test hole USW UZ-6s. 
Table 5. Summary of relation of gravimetric water-content measurements of composite core from test hole USW UZ-6s to lithology and degree of welding

[Michael Chornack, U.S. Geological Survey, written commun., 1985; all data values in gram per gram]

\begin{tabular}{|c|c|c|c|c|c|c|}
\hline Ceologic formation & $\begin{array}{l}\text { Number } \\
\text { of data } \\
\text { polnte }\end{array}$ & Data range & Average & Medlan & $\begin{array}{l}\text { Standard } \\
\text { doviation }\end{array}$ & $\begin{array}{l}\text { Degree of } \\
\text { welding }\end{array}$ \\
\hline $\begin{array}{l}\text { Tiva Canyon Member } \\
\text { (upper unit) of the } \\
\text { Paintbrush Tuff }\end{array}$ & 17 & 0.014 to 0.040 & 0.027 & 0.030 & 0.008 & Dense \\
\hline $\begin{array}{l}\text { Tiva Canyon Member } \\
\text { (lower vitrophyre) of the } \\
\text { Paintbrush Tuff }\end{array}$ & 4 & 0.040 to 0.068 & 0.054 & 0.054 & 0.012 & $\begin{array}{l}\text { Moderate to } \\
\text { dense }\end{array}$ \\
\hline $\begin{array}{l}\text { Tiva Canyon Member } \\
\text { (shardy base) of the } \\
\text { Paintbrush Tuff }\end{array}$ & 9 & 0.098 to 0.160 & 0.123 & 0.120 & 0.020 & $\begin{array}{l}\text { Partial to non- } \\
\text { welded }\end{array}$ \\
\hline Unnamed bedded tuff's & 12 & 0.050 to 0.205 & 0.106 & 0.106 & 0.044 & Not applicable \\
\hline $\begin{array}{l}\text { Topopah Spring Member } \\
\text { (vitric unit) of the } \\
\text { Paintbrush Tuff }\end{array}$ & 6 & 0.032 to 0.209 & 0.085 & 0.070 & 0.064 & Partial \\
\hline $\begin{array}{l}\text { Topopah Spring Member } \\
\text { (caprock) of the } \\
\text { Paintbrush Tuff }\end{array}$ & 17 & 0.010 to 0.040 & 0.027 & 0.031 & 0.009 & $\begin{array}{l}\text { Dense to } \\
\text { moderate }\end{array}$ \\
\hline
\end{tabular}

Thermocouple-voltage outputs are measured first on the calibration standards from lowest to highest molality, followed by the rock samples; then the measurements are repeated on the calibration standards from lowest to highest molality. The before-and-after selected voltage-output plateaus for each calibration standard are averaged to compensate for any drift in temperature (Brown, 1970). Each voltage-output plateau has two temperature readings, one taken before and one taken after the 10-minute period of voltageoutput measurements. The four temperature readings for each calibration standard are averaged. Each rock sample has a selected voltage-output plateau. The sample cups that contained the cuttings or core are carefully cleaned and dried after each set of measurements.

After all voltage-output readings are collected and voltage-output plateaus determined for calibration standards and rock samples, water potential is then calculated for each calibration standard. The calculated water potential is based on the molality of the calibration standard and the average temperature from the voltage-output measurement for that calibration standard. A linear-regression equation is run based on these calculated water potentials and the average of the before-and-after voltage-output plateaus for each calibration standard. The results of the linear-regression equation are used to construct the calibration curve and included intercept, slope, and coefficient of determination $\left(r^{2}\right)$. Using this calibration curve, the voltageoutput plateau reading from each cutting or core sample is entered into the linear-regression equation, and the output value is the water-potential value of the sample.

Generally, measurements of water potential of rock samples were rerun if the $r^{2}$ was less than 0.990 or if the readings did not plateau sufficiently. The calibration curves for cuttings and core from UZ-6s were almost linear, and $\mathrm{r}^{2}$ values ranged from 0.995 to 1.000 , with most $r^{2}$ values equal to 1.000 .

Results of water-potential measurements for UZ-6s are listed in tables 3 and 4 and shown in figure 5. For depths 120.7 to $150.6 \mathrm{~m}$, the water potential for coarse cuttings averaged $-37,000 \mathrm{kPa}$ and that for composite core averaged $-2,300 \mathrm{kPa}$.

Water-potential measurements are related to the degree of welding of tuff. Water-potential data of composite core from UZ-6s, as related to geological formation and degree of welding, are summarized in table 6. Only core data are tabulated; they are most representative of the rock units drilled. 


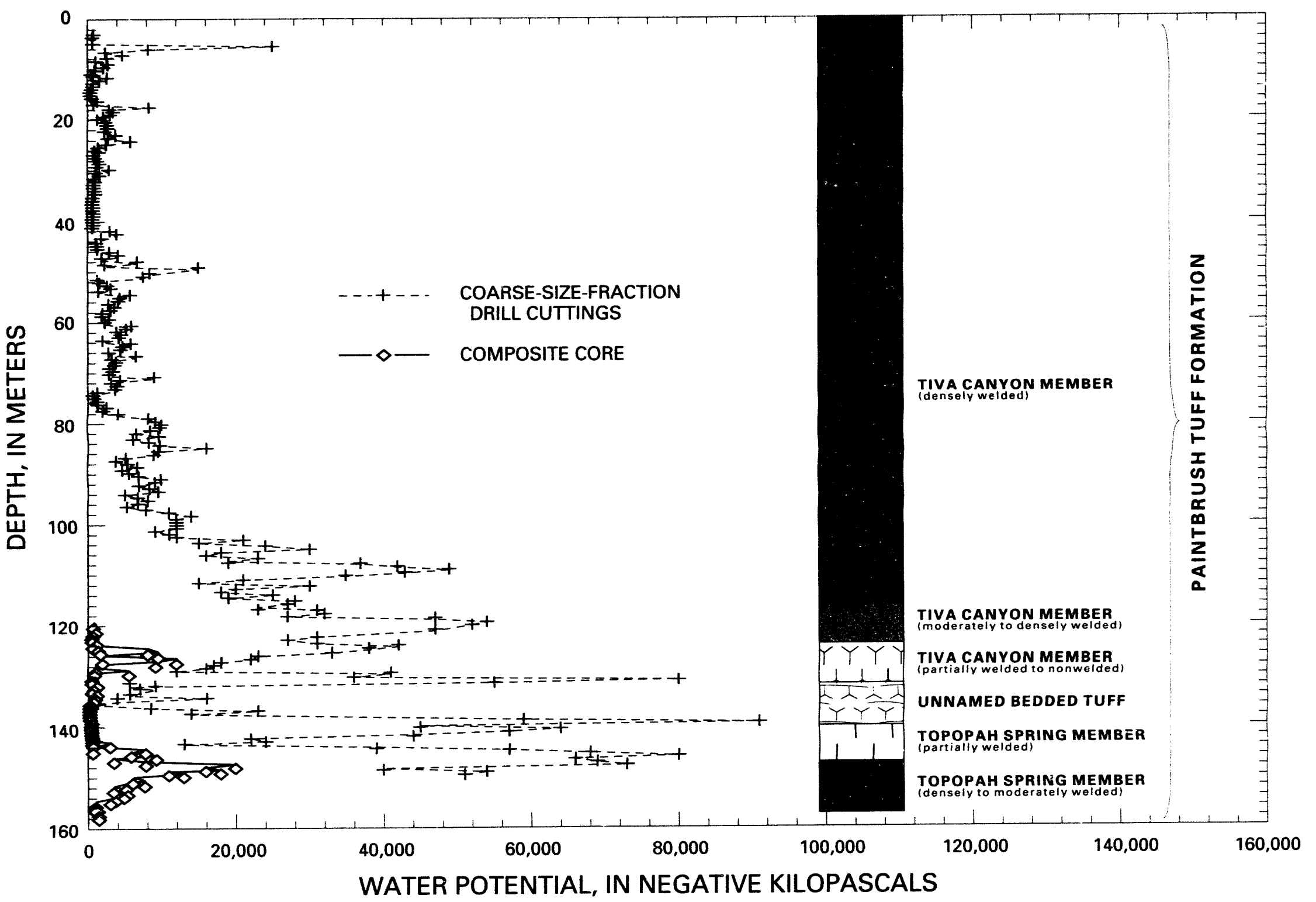

Figure 5. Water-potential measurements from coarse-size fraction drill cuttings and composite core from test hole USW UZ-6s. 
Table 6. Summary of relation of water-potential measurements of composite core from test hole USW UZ-6s to lithology and degree of welding

[Michael Chornack, U.S. Geological Survey, written commun., 1985; all data values in kilopascals]

\begin{tabular}{|c|c|c|c|c|c|c|}
\hline Goologic formation & $\begin{array}{l}\text { Number } \\
\text { of data } \\
\text { polnte }\end{array}$ & Data range & Average & Median & $\begin{array}{l}\text { Standard } \\
\text { deviation }\end{array}$ & $\begin{array}{l}\text { Degree of } \\
\text { welding }\end{array}$ \\
\hline $\begin{array}{l}\text { Tiva Canyon Member } \\
\text { (upper unit) of the } \\
\text { Paintbrush Tuff }\end{array}$ & 17 & $-1,000$ to $-20,000$ & $-7,200$ & $-5,200$ & $-6,100$ & Dense \\
\hline $\begin{array}{l}\text { Tiva Canyon Member } \\
\text { (lower vitrophyre) of the } \\
\text { Paintbrush Tuff }\end{array}$ & 4 & $-3,600$ to $-9,300$ & $-6,700$ & $-4,800$ & $-2,500$ & $\begin{array}{c}\text { Moderate to } \\
\text { dense }\end{array}$ \\
\hline $\begin{array}{l}\text { Tiva Canyon Member } \\
\text { (shardy base) of the } \\
\text { Paintbrush Tuff }\end{array}$ & 9 & -500 to $-7,800$ & $-1,700$ & -580 & $-2,400$ & $\begin{array}{l}\text { Partial to } \\
\text { nonwelded }\end{array}$ \\
\hline Unnamed bedded tuffs & 12 & -280 to -960 & -480 & -440 & -210 & $\begin{array}{c}\text { Not applica- } \\
\text { ble }\end{array}$ \\
\hline $\begin{array}{l}\text { Topopah Spring Member } \\
\text { (vitric unit) of the } \\
\text { Paintbrush Tuff }\end{array}$ & 6 & -520 to $-1,300$ & -820 & -680 & -340 & Partial \\
\hline $\begin{array}{l}\text { Topopah Spring Member } \\
\text { (caprock) of the } \\
\text { Paintbrush Tuff }\end{array}$ & 17 & -520 to $-12,000$ & $-3,400$ & $-1,200$ & $-3,900$ & $\begin{array}{l}\text { Dense to } \\
\text { moderate }\end{array}$ \\
\hline
\end{tabular}

\section{Bulk- and Grain-Density Measurements}

The bulk- and grain-density measurements of core samples from UZ-6s were determined by Holmes \& Narver Materials Testing Laboratory, Inc., at Mercury, Nev., in accordance with ASTM Procedure D-1188 (American Society for Testing and Materials, 1980a). Bulk density was calculated from bulk specific gravity.

After the bulk-density measurement was determined, each sample was pulverized to pass through a 200-mesh sieve, was oven-dried, and was tested in accordance with ASTM Procedure D-854 (American Society for Testing and Materials, 1980b), and grain density was calculated. Grain density refers to the weight of a substance compared with the weight of an equal volume of pure water at $4^{\circ} \mathrm{C}$. Results of laboratory analyses for bulk- and grain-density measurements for UZ-6s are listed in table 7 and are summarized in table 8. The bulk- and grain-density measurements of UZ-6s are shown in figure 6. 
Table 7. Results of laboratory analyses for bulk- and grain-density measurements of rotary-core samples from test hole USW UZ-6s

[Analyses by Holmes \& Narver Materials Testing Laboratory, Inc., Mercury, Nev.; --, no data]

\begin{tabular}{|c|c|c|}
\hline \multirow{2}{*}{$\begin{array}{l}\text { Depth interval of eample } \\
\text { (moters) }\end{array}$} & \multicolumn{2}{|c|}{$\begin{array}{c}\text { Density } \\
\text { (grams per cublc centimeter) }\end{array}$} \\
\hline & Bulk & Grain \\
\hline $23.26-23.32$ & 2.23 & 2.48 \\
\hline $23.41-23.47$ & 2.21 & 2.47 \\
\hline $29.41-29.50$ & 2.17 & 2.45 \\
\hline $35.36-35.97$ & 2.19 & 2.47 \\
\hline $41.45-41.57$ & 2.22 & 2.50 \\
\hline $41.97-42.06$ & 2.23 & 2.49 \\
\hline $48.01-48.16$ & 2.25 & 2.50 \\
\hline $60.26-60.35$ & 2.21 & 2.51 \\
\hline $78.03-78.14$ & 2.33 & 2.51 \\
\hline $84.12-84.73$ & 2.21 & 2.49 \\
\hline $90.22-90.50$ & 2.34 & 2.49 \\
\hline $96.71-96.90$ & 2.31 & 2.54 \\
\hline $102.82-102.96$ & 2.34 & 2.49 \\
\hline $108.72-108.81$ & 2.32 & 2.49 \\
\hline $114.60-114.73$ & 2.34 & 2.44 \\
\hline $120.93-121.10$ & 1.69 & 2.48 \\
\hline $122.53-122.62$ & 2.02 & 2.41 \\
\hline $122.93-123.02$ & 2.02 & 2.39 \\
\hline $123.84-123.93$ & 1.85 & 2.39 \\
\hline $124.45-124.54$ & 1.75 & 2.43 \\
\hline $125.27-125.39$ & 1.70 & 2.47 \\
\hline $126.13-126.22$ & 1.81 & 2.43 \\
\hline $127.10-127.19$ & 1.57 & 2.41 \\
\hline $127.86-127.96$ & 1.50 & 2.35 \\
\hline $128.32-128.44$ & 1.46 & 2.38 \\
\hline $128.93-129.02$ & 1.40 & 2.38 \\
\hline $129.84-130.12$ & 1.40 & 2.35 \\
\hline $130.58-130.67$ & 1.36 & 2.35 \\
\hline $131.37-131.46$ & 1.27 & 2.45 \\
\hline $131.98-132.10$ & 1.28 & 2.40 \\
\hline $132.47-132.59$ & 1.57 & 2.40 \\
\hline $133.29-133.41$ & 1.48 & 2.44 \\
\hline $133.84-133.96$ & 1.50 & 2.50 \\
\hline $134.84-134.97$ & 1.12 & 2.42 \\
\hline $135.39-135.48$ & 1.38 & 2.46 \\
\hline $136.61-136.79$ & 1.50 & 2.38 \\
\hline $137.95-138.07$ & 1.61 & 2.38 \\
\hline $138.47-138.59$ & 1.65 & 2.41 \\
\hline 139.39-139.48 & 1.31 & 2.50 \\
\hline $139.78-139.90$ & 1.74 & 2.50 \\
\hline $140.94-141.06$ & 1.58 & 2.50 \\
\hline
\end{tabular}


Table 7. Results of laboratory analyses for bulk- and grain-density measurements of rotary-core samples from test hole USW UZ-6s-Continued

\begin{tabular}{|c|c|c|}
\hline \multirow{2}{*}{$\begin{array}{l}\text { Depth interval of sample } \\
\text { (moters) }\end{array}$} & \multicolumn{2}{|c|}{$\begin{array}{c}\text { Density } \\
\text { (grams per cublc centimoter) }\end{array}$} \\
\hline & Bulk & Graln \\
\hline $141.61-141.70$ & 1.29 & 2.65 \\
\hline $142.19-142.28$ & 1.66 & 2.53 \\
\hline $143.87-144.02$ & 1.53 & - \\
\hline $146.30-146.36$ & 1.61 & 2.45 \\
\hline $146.97 \ldots 147.16$ & 2.16 & 2.51 \\
\hline $147.34-147.46$ & 2.34 & 2.54 \\
\hline $148.10-148.19$ & 2.23 & 2.57 \\
\hline $149.44-148.56$ & 2.31 & 2.58 \\
\hline $148.96-149.08$ & 2.24 & 2.58 \\
\hline $149.15-149.29$ & 2.28 & 2.54 \\
\hline $149.50-149.60$ & 2.17 & 2.60 \\
\hline $150.75-150.88$ & 2.23 & 2.57 \\
\hline $150.88-151.06$ & 2.15 & 2.58 \\
\hline $151.97-152.03$ & 2.13 & 2.56 \\
\hline $152.40-152.55$ & 2.12 & 2.59 \\
\hline $153.25-153.31$ & 2.14 & 2.58 \\
\hline $153.77-153.92$ & 2.15 & 2.59 \\
\hline $155.05-155.4$ & 2.16 & 2.57 \\
\hline $155.36-155.48$ & 2.14 & 2.56 \\
\hline $156.09-156.18$ & 2.13 & 2.57 \\
\hline $157.31-157.46$ & 2.08 & 2.56 \\
\hline $157.76-157.86$ & 2.07 & 2.59 \\
\hline
\end{tabular}

Table 8. Summary of relation of bulk- and grain-density measurements of composite core from test hole USW UZ-6s to lithology and degree of welding

[Michuel Chornack, U.S. Geological Survey, written commun., 1985; all data values in grams per cubic centimeter]

\begin{tabular}{|c|c|c|c|c|c|}
\hline Geologic formition & $\begin{array}{l}\text { Range of } \\
\text { values }\end{array}$ & Average & $\begin{array}{l}\text { Range of } \\
\text { value: }\end{array}$ & Average & $\begin{array}{l}\text { Degree of } \\
\text { welding }\end{array}$ \\
\hline $\begin{array}{l}\text { Tiva Canyon Member } \\
\text { (upper unit) of the } \\
\text { Painebrush Tuff }\end{array}$ & 2.17 to 2.34 & 2.26 & 2.44 to 2.54 & 2.49 & Dense \\
\hline $\begin{array}{l}\text { Tiva Canyon Member } \\
\text { (lower vitrophyre) of the } \\
\text { Paintbrush Tuff }\end{array}$ & 1.69 to 2.02 & 1.90 & 2.39 to 2.48 & 2.42 & $\begin{array}{c}\text { Moderate to } \\
\text { dense }\end{array}$ \\
\hline $\begin{array}{l}\text { Tiva Canyon Member } \\
\text { (shardy base) of the } \\
\text { Paintbrush Tuff }\end{array}$ & 1.36 to 1.81 & 1.55 & 2.35 to 2.47 & 2.39 & $\begin{array}{l}\text { Partial to non- } \\
\text { welded }\end{array}$ \\
\hline Unnamed bedded tufis & 1.12 to 1.74 & 1.45 & 2.23 to 2.50 & 2.42 & Not applicable \\
\hline $\begin{array}{l}\text { Topopah Spring Member } \\
\text { (vitric unit) of the } \\
\text { Paintbrush Tuff }\end{array}$ & 2.07 to 2.34 & 1.64 & 2.45 to 2.65 & 2.53 & Fartial \\
\hline $\begin{array}{l}\text { Topopah Spring Member } \\
\text { (caprock) of the } \\
\text { Paintbrush Tuff }\end{array}$ & 2.07 to 2.34 & 2.18 & 2.54 to 2.60 & 2.57 & $\begin{array}{c}\text { Dense to moder- } \\
\text { ate }\end{array}$ \\
\hline
\end{tabular}




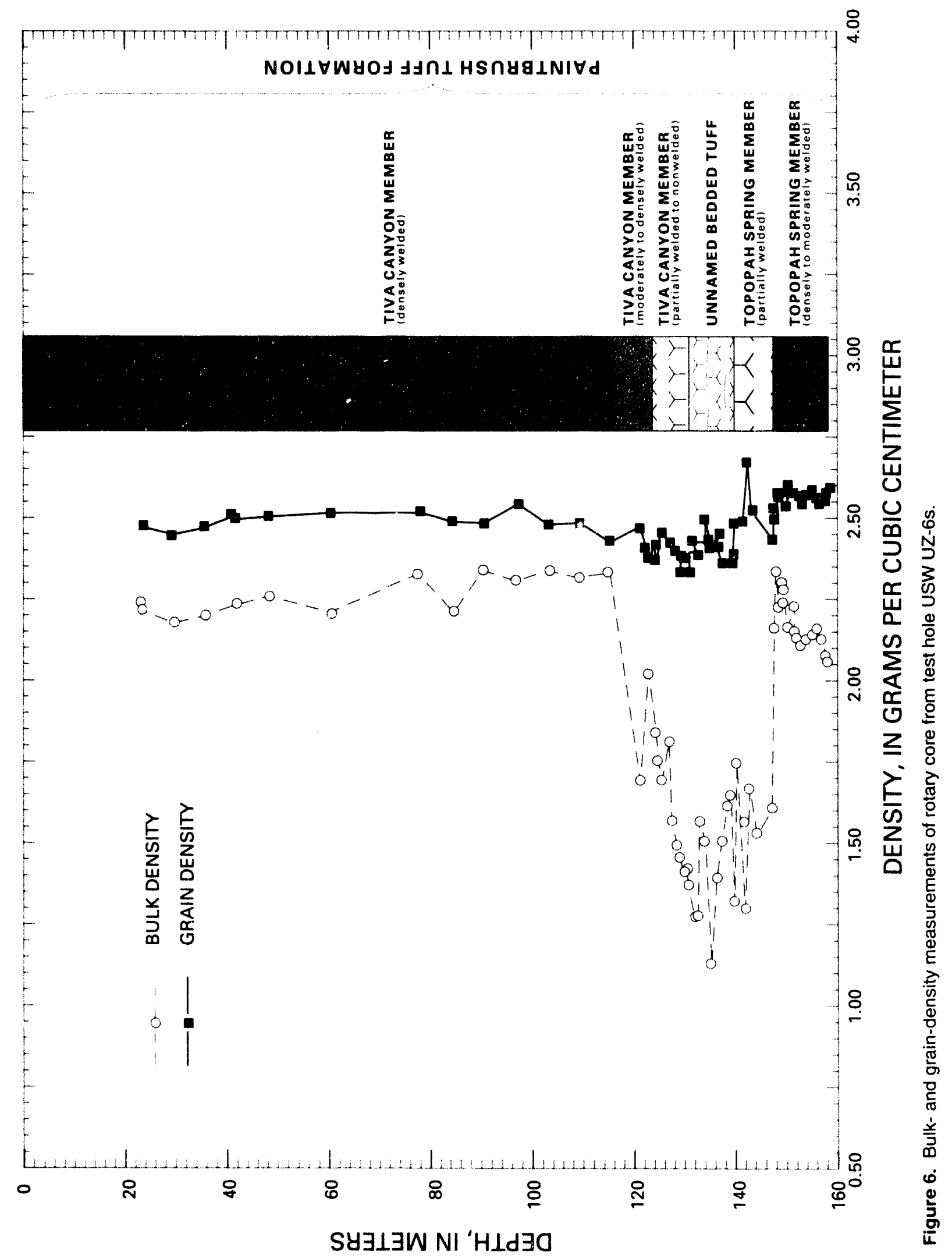




\section{SUMMARY}

Test hole UZ-6s located on the crest of Yucca Mountain was drilled to a depth of $158.2 \mathrm{~m}$. Cutting and core samples were collected to determine gravimetric water-content, water-potential, bulk-density and grain-density measurements. Geologic formations penetrated are the Tiva Canyon Member, unnamed bedded tuff, and Topopah Spring Member of the Paintbrush Tuff.

\section{SELECTED REFERENCES}

American Society for Testing and Materials, 1980a, Standard test method for bulk specific-gravity of compacted bituminous mixtures using paraffin-coated specimens: Philadelphia, Pa., Annual Book of ASTM Standards, v. 19, ANSI-ASTM D 1188-71 (reapproved in 1976), p. 247-248. (NNA.900622.0435) $1980 \mathrm{~b}$, Standard test method for specific gravity of soils: Philadelphia, Pa., Annual Book of ASTM Standards, v. 19, ANSI ASTM D 854-58 (reapproved in 1979), p. 211-213. (NNA.900622.0434)

Brown, R.W., 1970, Measurement of water potential with thermocouple psychrometers--Construction and applications: U.S. Forest Service Research Paper INT-80, 27 p. (NNA.900208.0001)

Gardner, W.H., 1965, Water content, Black, C.A., ed., Methods of soil analyses--Pt. 1, Physical and mineralogical properties, including statistics of measurement and sampling: Madison, Wis., American Society of Agronomy, Agronomy Monograph 9, p. 82-127. (NNA.900208.0007)

Guzowski, R.V., Nimick, F.B, Siegel, M.D, and Finley, N.C., 1983, Repository site data report for tuff, Yucca Mountain, Nevada: Albuquerque, N.Mex., Sandia National Laboratories, Report NUREG/CR-2937; SAND822105,327 p. (NNA.870519.0037)

Hammermeister, D.P., Blout, D.O. and McDaniel, J.C., 1985, Drilling and coring methods that minimize the disturbance of cuttings, core, and rock formation in the unsaturated zone, Yucca Mountain, Nevada, in National Water Well Association Conference on Characterization and Monitoring of the Vadose (Unsaturated) Zone, Denver, 1985, Proceedings: Worthington, Ohio, National Water Well Association, p. 507-541. (HQS.880517.2696)
Kume, Jack and Hammermeister, Dale P., 1990, Geohydrologic data from test hole USW UZ-7, Yucca Mountain area, Nye County, Nevada: U.S. Geological Survey Open-File Report 88-465, 37 p. (NNA.900312.0300) 1991, Geohydrologic data from drill-bit cuttings and rotary cores from test hole USW UZ-13, Yucca Mountain area, Nye County, Nevada: U.S. Geological Survey Open-File Report 90-362, 30 p. (NNA.901015.0196)

Loskot, C.L. and Hammermeister, D.P., 1986, Geohydrologic data from test holes UE-25 UZ \#4 and UE-25 UZ \#5, Nevada Test Site, Nye County, Nevada: U.S. Geological Survey Open-File Report 90-369, 57 p. (NNA.911219.0001)

Montazer, Parviz, and Wilson, W.E., 1984, Conceptual hydrologic model of flow in the unsaturated zone, Yucca Mountain, Nevada: U.S. Geological Survey Water-Resources Investigations Report 84-4345, 55 p. (NNA.870519.0109)

Mower, T.E., Higgins, J.D., and Yang, I.C., 1990, Triaxial and uniaxial compression testing methods developed for extraction of pore water from unsaturated tuff, Yucca Mountain, Nevada, in FOCUS ' 89 Nuclear waste isolation in the unsaturated zone, Proceedings: LaGrange Park, IIl, American Nuclear Society, p. 426-433. (NNA.901214.0002)

Richard, L.A., 1942, Soil moisture tensiometer materials and construction: Soil Science, v. 53, January-June, p. 241-248. (NNA.900208.0080)

Richards, L.A., and Ogata, G., 1958, Thermocouple for vapor pressure measurements in biological and soil systems at high humidity: Science, v. 128, no. 3331, p. 1089-1090. (HQS.880517.2837)

Whitfield, M.S., Cope C.M., and Loskot, C.L., 1992, Borehole and geohydrologic data for test hole USW UZ-6, Yucca Mountain, Nye County, Nevada: U.S. Geological Survey Open-File Report 92-28, 36 p. (NNA.920123.0088) 


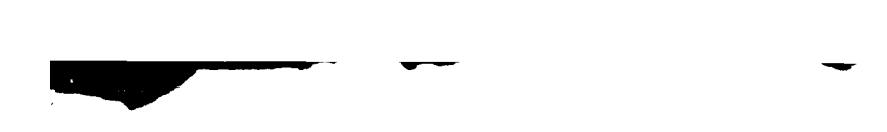

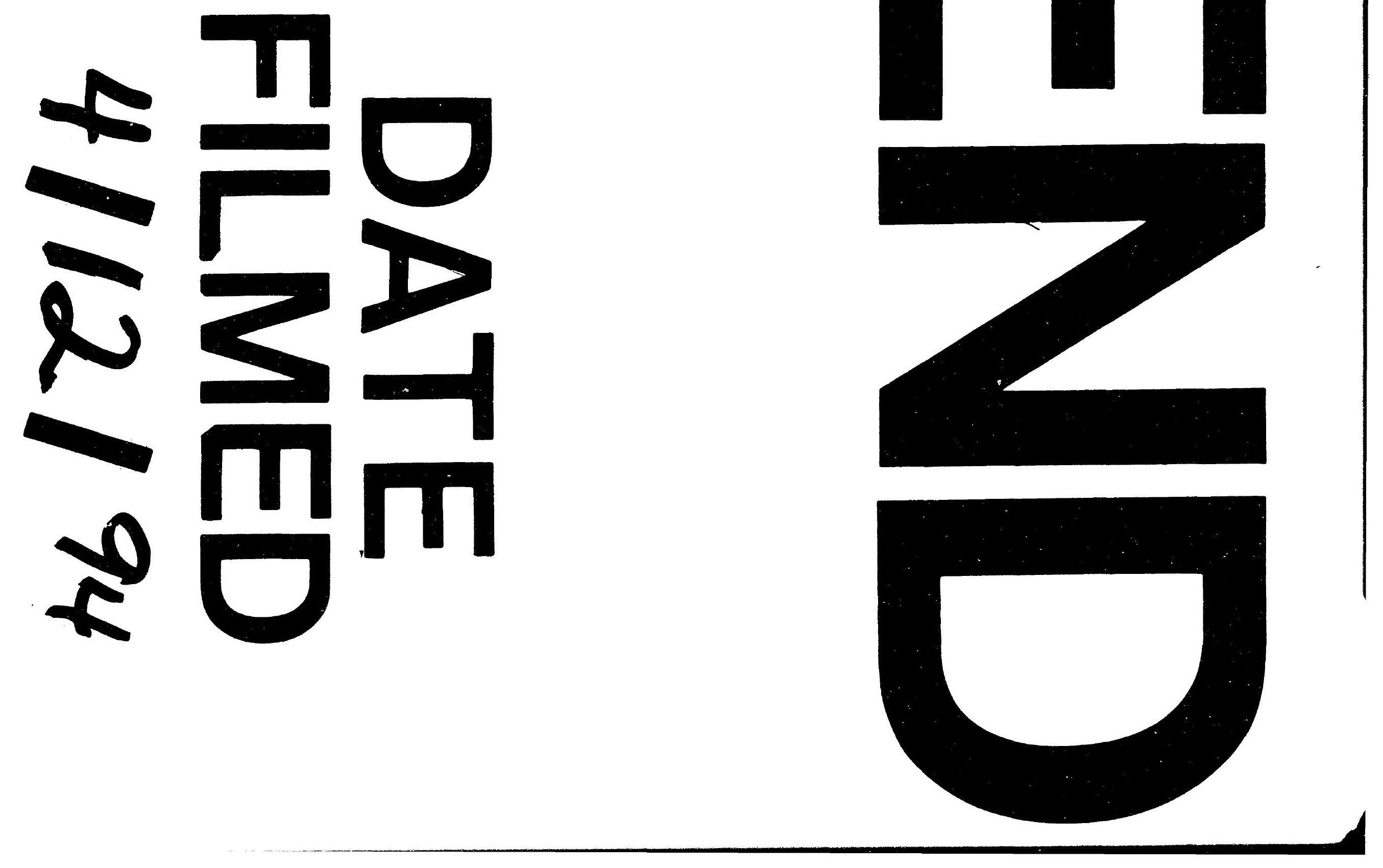


